This document is the accepted manuscript version of the following article:

Stäh7y, S., Franca, M. J., Robinson, C. T., \& Schleiss, A. J. (2020). Erosion, transport and deposition of a sediment replenishment under flood conditions.

Earth Surface Processes and Landforms. https://doi.org/10.1002/esp.4970

\title{
1 Erosion, transport and deposition of a sediment replenishment 2 under flood conditions
}

4 Running head: Sediment replenishment under flood conditions

6 Severin Stählya*, Mário J. Franca ${ }^{\mathrm{b}, \mathrm{c}}$, Christopher T. Robinson ${ }^{\mathrm{d}}$ and

7 Anton J. Schleiss ${ }^{a}$

8 aLaboratoire de Constructions Hydrauliques (LCH), École Polytechnique

9 Fédérale de Lausanne (EPFL), Lausanne, Switzerland; blHE Delft Institute for

10 Water Education, Delft, The Netherlands; ' ${ }^{D}$ Department of Hydraulic

11 Engineering, Delft University of Technology, Delft, The Netherlands; ${ }^{d}$ Aquatic

12 Ecology Department, Swiss Federal Institute of Aquatic Science and

13 Technology (EAWAG), Dübendorf, Switzerland

14

*corresponding author: Laboratoire de Constructions Hydrauliques (LCH), École 5525. E-mail: sev.staehly@gmail.com. 
Abstract: River reaches downstream of dams with constant residual discharge often lack sediment supply and periodic high flows due to dam sediment retention and flow regulation, respectively. To test a novel multideposit methodology for defining environmental flows, activating dynamics of river morphology downstream of dams, a flood was released from Rossens Dam in Switzerland. This event was combined for the first time with a multi-deposit configuration of sediment replenishment consisting of four artificial deposits allocated as alternate bars along the river banks as a restoration measure. To validate the sediment transport behaviour observed in laboratory tests, stones were equipped with RFID PIT tags, a fix-antenna was installed at the river bed and a mobile antenna was used to allow the investigation of erosion, transport and deposition of replenished sediments. The extension of the erosion period was determined for the tracked stones and average transport velocities were found on the order of $10^{-3} \mathrm{~m} / \mathrm{s}$. To estimate the erosion efficiency of the flood, defined as the eroded tagged stones compared to the released water volume, the hydrograph was divided in different periods: rising limb, constant peak discharge, decreasing limb. During the rising limb of the flood, which lasted for $20 \%$ of the total flood duration, more than $40 \%$ of the PIT tags were transported. The defined erosion efficiency is a measure to support the hydrograph design of artificial flood releases at dams. The deposition of tagged stones resulted in a repeating cluster formation as expected from previous laboratory experiments, creating an increase in hydraulic habitat diversity. The analogy of results from field and laboratory experiments confirmed the robustness of the multi-deposit sediment replenishment method. Combined with the gained knowledge of the erosion efficiency, results could spark further application and research of multi-deposit sediment replenishment techniques as a habitat oriented river restoration measure.

Keywords: sediment transport, river morphology, RFID PIT tags, river restoration, sustainable hydropower management, artificial flood release 
Flow and sediment regimes are two key drivers of morphology and functioning in riverine ecosystems and associated floodplains (Poff et al., 1997; Wohl et al., 2015) that host a large variety of habitats (Sparks 1995; Allan and Castillo 2007; Stähly et al. 2019a). Storage dams have severe impacts on these drivers, causing residual flow conditions due to flow regulation and, in the case of hydropower dams, hydropeaking conditions through energy production (Magilligan and Nislow, 2005; Moyle and Mount, 2007). Large reservoirs retain almost all coarse sediment transported by rivers. The sediment continuum is often completely interrupted in long reservoirs (Schleiss et al., 2016; Warner, 2012). The absence of periodic flood events and sediment supply leads to incision of downstream river beds, loss of fluvial connectivity and, over time, to colonialization of biotopes (e.g. gravel bars) by species that prefer a more static environment such as hardwoods that are limited in dynamic riverine systems.

Reservoir flushing is required to ensure a sustainable dam management, thus dam operators do it periodically (Kantoush and Schleiss, 2009; Schleiss et al., 2016). Such flushing operations can be designed to restore sediment dynamics and associated ecological functions in residual flow reaches (Cross et al., 2011; Kondolf and Wilcock, 1996; Konrad et al., 2011; Loire et al., 2019; Poff et al., 1997; Poff and Schmidt, 2016). An example of this is the extensive long-term study of artificial flood releases at the Spöl river, Switzerland, which has been conducted since 2000 and has changed the diversity of macroinvertebrates (Robinson, 2012; Robinson et al., 2018; Robinson and Uehlinger, 2008). Artificial flood releases have been widely studied all over the world (Konrad et al., 2011). Where feasible, sediment should be added to such 
artificial floods to restore river dynamics and hydraulic variability; so-called sediment replenishment. This is also a widely applied technique without artificial flood releases (Arnaud et al., 2017; Gaeuman, 2012; Gaeuman et al., 2017; Hassan and Zimmermann, 2012; Heckmann et al., 2017; Wilcock et al., 1996). Lately, extensive joint research efforts were performed to study erosion, transport and deposition processes of sediment replenishment in the laboratory (Battisacco, 2016; Battisacco et al., 2016; Cui et al., 2003; Friedl et al., 2018;

Sklar et al., 2009). Friedl et al. (2018) looked at rivers with a gentle slope $(0.17 \%)$ and investigated erosion processes of different dimensions of a single artificial deposit adjacent to the river bank. This is a common practice in sediment replenishment (Kondolf, 1997), and they came up with a method to predict the erosion rate of such a single deposit replenishment. Battisacco reach resulted in a repetitive pattern of sediment clusters, leading to an increase in morphological diversity (Battisacco et al. 2016; Juez et al. 2016; Stähly et al. 2019b). However, the detailed erosion, transport and deposition processes have not been studied in the field, and is the aim of the presented 100 research here. Sediment transport processes can be investigated in the field using 102 Radio-Frequency IDentification technology, RFID ( Brousse et al., 2019; 103 Lamarre et al., 2005; Olinde and Johnson, 2015; Slaven et al., 2014). Passive 
104 Integrated Transponder (PIT) tags have been successfully used in sediment

105 replenishment projects. Tags are fixed inside stones with little effort and can

106 then be detected with an antenna (Lamarre and Roy, 2008; MacVicar and Roy,

107 2011; Nathan Bradley and Tucker, 2012). Thus far, RFID PIT tags proved to be

108 a useful technology in up to waist-deep water (Hassan and Roy, 2016; Liébault

109 et al., 2012). Studies in different fluvial environments resulted in recovery rates

110 from around $10 \%$ in larger to over $85 \%$ in smaller rivers (Arnaud et al., 2017;

111 Brenna et al., 2019; Lamarre et al., 2005; Schneider et al., 2010). PIT tags are

112 relatively inexpensive, allowing the use of several hundreds of such tags. A

113 large quantity of PIT tags can compensate for the difficulties of recovering them.

114 Compared to active RFID tags, passive tags have a short detection distance.

115 Furthermore, PIT tags have an "unlimited" life time since they do not include a

116 battery. This allows long-term studies and giving still useful results if certain

117 tags left the study perimeter, destroyed, or lost.

\section{Research objectives}

119 In the framework of an artificial flood release, the erosion, transport and

120 deposition of a multi-deposit sediment replenishment, previously analyzed in

121 laboratory experiments and promising an increase of morphological diversity,

122 was investigated outside of the laboratory, using RFID PIT tags. Besides the

123 investigation of the different processes, the field experiment was also compared

124 with the laboratory tests of Battisacco et al. (2016). The analysis of the erosion

125 efficiency for different periods of the flood hydrograph (percentage of eroded

126 stones divided by the percentage of the released amount of water) provided

127 useful information for the practical application of artificial flood releases and 
128 sediment replenishment below dams. Aspects of the artificial flood can be found

129 in the supplementary data $51-2$.

\section{Study area}

131 The study took place at the Sarine River in western Switzerland. The

132 Sarine is a bed-rock alluvial river that originates upstream of Lac de Sénin at

133 the Sanetsch at $2252 \mathrm{~m}$ a.s.I. It drains a catchment of $1900 \mathrm{~km}^{2}$ into the Aare,

134 which is a tributary of the Rhine. Six reservoirs for hydropower production are

135 located along the $125-\mathrm{km}$ long river, resulting in a regulated flow regime. In

136 1948, an 83-m high arch dam was constructed in Rossens, creating the over

137 13-km long Lac de la Gruyère, with a reservoir volume of 200 million $\mathrm{m}^{3}$. The

138 dam is located in a pre-alpine valley leading to a relatively long reservoir that

139 completely interrupts the sediment continuum. The downstream floodplain is

140 located in a natural landscape of a 100-m deep incised and 40 to $100 \mathrm{~m}$ wide

141 canyon. The canyon is surrounded by agriculture and small villages. Man-made

142 structures in the floodplain are limited to a handful of buildings and some gravel

143 roads and hiking paths. The absence of flood events and interruption of

144 sediment supply reduced sediment dynamics and enhanced channel incision,

145 resulting in a lateral disconnection of the floodplain (see supplementary data

146 S3). Vegetation colonized the gravel bars, which are now populated with willows

147 and hardwood (Döring et al., 2018; Milani et al., 2018).

148 A residual discharge of $2.5-3.5 \mathrm{~m}^{3} / \mathrm{s}$ is released at Rossens Dam,

149 creating a 13.4-km long by-pass reach until the outflow of the powerhouse in

150 Hauterive (see Figure 1a). There, four Francis turbines release up to $75 \mathrm{~m}^{3} / \mathrm{s}$

151 into the Sarine during electricity production. 
A large-scale field experiment was launched in 2016 to simulate a

153 dynamic flow and sediment regime in the Sarine floodplain. Flood frequency

154 and magnitude decreased in this river segment since the construction of

155 Rossens Dam. The median of the maximal measured discharge at the gauging

156 station in Fribourg decreased from $304 \mathrm{~m}^{3} / \mathrm{s}$ (pre-dam period 1911-1947) to 165

$157 \mathrm{~m} 3 / \mathrm{s}$ (recent decades 1990-2016). There are two small tributaries between the

158 power station in Hauterive and the gauging station in the city of Fribourg.

\section{Restoration framework}

160 Multi-deposit replenishment configuration

161 The replenishment was added in four artificial deposits of sediment and placed

162 in the river at the coordinates $46^{\circ} 45^{\prime} 29.21^{\prime \prime} \mathrm{N} / 7^{\circ} 06^{\prime} 11.47^{\prime \prime} \mathrm{E}$. The configuration

163 was an adaptation to field conditions of the sediment replenishment successfully

164 tested previously in flume experiments. Numerous multi-deposit replenishment configurations were tested in the flume and the selected setup led to a formation of clusters like alternate bars and hence increased habitat diversity (Battisacco

167 et al., 2016). Figure $1 \mathrm{~b}$ provides a top-view of the multi-deposit configuration in

168 the Sarine, and Figure 2 an example of one artificial sediment deposit. The main

169 specifications of the field and laboratory experiments are given in Table 1 . The

170 replenished sediment was excavated from the adjacent alluvial forest on the

171 orographic right side of the river. Thus, we could assume that the sediment

172 replenishment has the same grain size distributions as the river bed subsurface.

173 The sediment was distributed in the river without sorting. The excavated

174 material was composed of characteristic grain sizes $d_{m}=57 \mathrm{~mm}$ and $d_{90}=113$ $\mathrm{mm}$. The d90 corresponds to the grain size of the armor layer in the river bed. 
176 The grain size distribution was determined by analyzing 21 samples using

177 pebble counts (Fehr, 1987) and photo sieving from BASEGRAIN (Stähly et al.,

178 2017). The fine sediment for $d_{m}$ and $d_{90}$ was estimated as $25 \%$ (Fehr, 1987).

179 Where the sediment was excavated, ponds with still water were created, serving

180 additionally as habitats for amphibians and other species (see supplementary

181 data S4).

182 [Figure 1]

183 [Figure 2]

184 [Table 1]

185 Artificial flood release

186 The artificial flood release was led by cantonal authorities in collaboration with

187 the research institutes École Polytechnique Fédérale de Lausanne, Swiss

188 Federal Institute of Aquatic Science and Technology, University of Zurich and

189 Zurich University of Applied Sciences, as well as with the participation of

190 engineering offices (Pronat, Hydrique), NGO's and the dam owner (Groupe e).

191 A slightly right-skewed hydrograph had a gradual increase up to a peak

192 discharge of $195 \mathrm{~m}^{3} / \mathrm{s}$, corresponding to a two-year flood, was released from

193 Rossens Dam on 14 September 2016 and lasted about 28 hours (Figure 9 and

194 Table 4). The main purpose was to clean the river of excess algae, hence flip

195 each stone of the bed surface once. This gave us the opportunity to test the

196 behavior of this multi-deposit sediment replenishment in the field and to study

197 its local impact. Given the initial flood purpose, the threshold for the destruction

198 of the armor layer in the river bed was not exceeded to a large extent.

199 According to studies done by engineers, the critical discharge for onset of

200 movement is some $150 \mathrm{~m}^{3} / \mathrm{s}$ for a diameter corresponding to $d_{90}$. To initiate 
sediment transport, the shape of the hydrograph was chosen accordingly; peak

202 discharge was kept for two hours with a gradual decrease.

\section{Methodology}

204 Sediment tracking system

205 A total of 489 cobbles, divided in $d_{m}$ and $d_{90}$, were collected in the field, drilled,

206 the hole filled with an RFID PIT tag of $32 \mathrm{~mm}$ and $23 \mathrm{~mm}$ length (depending on

207 stone size) and sealed with silicon (Arnaud et al., 2015; Cassel et al., 2017b).

208 The modal diameter $d_{m}$ was chosen to represent the entire grain size

209 distribution and $d_{90}$ for characterizing the armor layer of the river bed, if there

210 was an armor layer. The shape characteristics of the equipped stones was

211 different between $d_{m}$ and $d_{90}$. Despite the small variation in $b$-axis, the weight

212 varied significantly, especially for $d_{90}$. Most $d_{90}$ stones were disc-shaped, while

213 the shape of $d_{m}$ stones were more diverse (Figure 3a-c). With the software

214 S2_Util (Texas Instruments TIRIS, Version 1.20), tags were programmed with a

215 unique identification number. After measuring the three axes and the weight of

216 the tagged cobbles, they were distributed equally in three layers (surface, $0.5 \mathrm{~m}$

$217-1.0 \mathrm{~m}$ and ca. $1.5 \mathrm{~m}$ ) in the four artificial deposits (Figure $1 \mathrm{~b}$ ).

218 About $100 \mathrm{~m}$ downstream of artificial deposit IV, a pass-over loop fix-

219 antenna was mounted across the river, perpendicular to the main flow direction

220 (Schneider et al., 2010). The antenna consisted of a single loop multiple strand

221 cable with a diameter of $16 \mathrm{~mm}^{2}$, protected by a rubber hose (Figure 4). The

222 hose was fixed with cable straps close to the river bed at 1-m long armoring

223 irons that were vertically installed into the river bed every meter. Prior to its

224 installation, the antenna shape was optimized to a length corresponding to the 
225 local river width of about $25 \mathrm{~m}$. The optimal antenna surface of $25 \mathrm{~m} \times 0.3 \mathrm{~m}$

226 resulted in a detection distance of up to $1.5 \mathrm{~m}$ under dry conditions. Installed in

227 the river, the detection range under water did not exceed $0.3 \mathrm{~m}$. The loss of

228 detection distance may likely be from the limited structural rigidity of the

229 antenna respectively its fixation at the river bed.

$230 \quad$ [Figure 3]

231 [Figure 4]

232 In addition to the fixed antenna, a mobile antenna was used for RFID PIT

233 tag detection after the flood. The mobile antenna consisted of a $1.5 \mathrm{~m}$ long pole

234 and $0.7 \mathrm{~m}$ diameter ring attached at the end, both made of plastic (S5). Inside

235 the ring, a double loop of $4 \mathrm{~mm}^{2}$ multiple-strand cable formed the antenna

236 resulting in a maximal detection distance of some $0.60 \mathrm{~m}$. The electro-magnetic

237 components are carried in a back pack. When detecting a PIT tag, the antenna

238 made a noise and the tag ID was shown on the screen. Both antenna systems

239 worked with a 12 V 7.0 Ah battery. The electromagnetic components, such as

240 the PIT tags, Tuning Board, HDX Reader and Control board are products from

241 OREGON RFID, Portland, USA. The PIT tags work at a low frequency of

$242134.2 \mathrm{kHz}$, allowing detection in submerged conditions.

243 With the help of the self-made mobile RFID antenna, the location of

244 tagged stones could be detected after the flood event and their locations were

245 recorded with a differential Global Navigation Satellite System (GNSS, model

246 TOPCON HiPer Pro) with an accuracy of a few centimeters. The location of

247 origin $\left(x_{0}\right)$ and deposition $\left(x_{d}\right)$ for tagged stones could therefore be captured

248 with a precision of ca. $1 \mathrm{~m}$ due to the antenna-size. The location of the fix-

249 antenna $\left(x_{a}\right)$ was known. In addition, the replenishment zone was defined, 
covering the influence area of the artificial deposits where flow varies highly. It

251 reaches from the upstream end of artificial deposit I until one river width

252 downstream of artificial deposit IV $\left(x_{e}\right)$. The definition of this spatial division is

253 given in Figure 5.

254 [Figure 5]

Knowing the location of deposition of a tagged stone $\left(x_{d}\right)$, the time it ceased moving $\left(t_{d}\right)$, the time it passed the antenna $\left(t_{a}\right)$ and the location of the antenna $\left(x_{a}\right)$, an average transport velocity $\left(v_{d}\right)$ for each stone that passed the fix-antenna can be estimated for the distance between the fix-antenna and the location of final settling (Eq. 1). This measured average transport velocity, referred to as virtual velocity $v_{d}$, is the average of a series of bouncing and stopping processes within the interval of $x_{a}$ and $x_{d}$ in the allocated time period

262 (Hassan et al., 1991). On the other hand, the velocity upstream of the antenna $\left(v_{a}\right)$ can be calculated (Eq. 2), using the time and location at the antenna $\left(t_{a}, x_{a}\right)$ with its departing location $\left(x_{0}\right)$ and earliest possible moment for erosion $\left(t_{0}\right)$, which depends on the discharge. The erosion time $\left(t_{e}\right)$ indicates the time a

266 tagged stone is transported out of the replenishment zone and can be obtained by Equation 3 and the estimation of the erosion velocity $v_{e}$ according to

268 Equation 4 (see Figure 6). The erosion times are visualized in a survivor plot 269 (Davison and Hinkley, 1997), allowing the determination of the erosion-effective 270 periods during the flood event as well as the corresponding sedigraph. The 271 sedigraph represents the time-series of the erosion of the tagged stones and combined with the released volume the erosion efficiency is calculated (eeff, see Equation 5). The eeff is defined as the ratio between the percentage of 
274 eroded tags in a certain time period $\left(\Delta t_{i}\right)$ and the percentage of released water

275 during the same time period.

$$
\begin{gathered}
v_{d}=\frac{x_{d}-x_{a}}{t_{d}-t_{a}} \\
v_{a}=\frac{x_{a}-x_{0}}{t_{a}-t_{0}} \\
t_{e}=t_{d}-\frac{x_{d}-x_{e}}{v_{d}} \\
v_{e}=\frac{x_{e}}{t_{e}} \\
\text { eeff } f_{i}=\frac{\text { Eroded tags (during } \left.\Delta t_{i}\right)}{\text { Released water volume }\left(\text { during } \Delta t_{i}\right)[\%]}
\end{gathered}
$$

277 [Figure 6]

278 Critical discharge to determine to and $t_{d}$

279 The critical discharge for the $d_{m}$ and $d_{90}$ on each artificial deposit was

280 determined using a numerical 2D-flow-model in BASEMENT (see

281 www.basement.ethz.ch). The node spacing in the wetted area was $2 \mathrm{~m}$, and

282 calibration was done with the maximum water depth observed during the flood

283 event. The river bed was modelled as a fixed bed and the artificial deposits with

284 a mixed grain size, with both diameters, $57 \mathrm{~mm}\left(d_{m}\right)$ and $113 \mathrm{~mm}\left(d_{90}\right)$. Two

285 different sediment transport equations were applied (Meyer-Peter and Müller,

286 1948; Parker, 1990) to observe the incipient motion of the grain sizes at each

287 artificial deposit based on the shields criteria. The globally smallest critical

288 discharge was used as the deposition criterion on the decreasing limb of the 
289 hydrograph (more information in the supplementary data S8). The resulting

290 discharges are given in Table 3.

\section{Comparison with the laboratory experiments}

292 To compare the experiment with the laboratory findings, the deposition pattern

293 of the replenished sediment was analysed using two metrics that were

294 investigated by Battisacco et al. (2016): the occupation ratio along the channel

295 (OCR) and the different wavelengths of the OCR longitudinal distribution, which

296 represents a measure of the reoccurrence of sediment clusters. In the

297 laboratory experiments, the OCR is defined as the percentage of red pixels (red

298 pixels $=$ replenishment) in an analyzed cross-section with the interval size of

299 one pixel $x$ (Eq. 6). In the field, the OCR was calculated based on the number of

300 tagged stones found in a certain river interval $(X)$. Therefore, the length of the

301 river was fragmented into 5-m-intervals between the downstream end of

302 artificial deposit IV and the last tagged stone found (see Figure 7). To normalize

303 the data and allowing comparison with the laboratory data, the maximal number

304 of tagged stones detected in a 5-m-interval was taken (Eq. 7). The periodicity in

305 the longitudinal direction of the river can be calculated with the Fourier

306 transformation of the OCR (Stoica et al., 2005). A more detailed calculation

307 procedure of OCR and periodicity is given by Battisacco (2016).

$$
O C R_{x, l a b}=\frac{\sum \text { red pixels in a cross section }}{\sum \text { pixels in a cross section }}
$$

$O C R_{X, f i e l d}$

$=\frac{\sum \# \text { of tagged stones in a } 5 \text { m interval }}{\sum \text { maximal \# of tagged stones recovered in a } 5 \text { m interval }}$ 


\section{Sediment tracking}

310 From the 489 RFID tagged stones placed in the artificial deposits, 277 were

311 found and localized with the mobile antenna after the flood event (Stähly et al., 312 2018). Out of these 277 stones, 166 were located in the river and 111 in the

313 remaining part of the partially eroded artificial deposits. From these 166 stones,

31484 were detected downstream of the replenishment zone. Air images revealed

315 that artificial deposit I, II and IV were only partially eroded (Figure 7). Stones

316 from artificial deposit I and III were transported the furthest, stones from artificial

317 deposit II the least (Figures 7 and 8). The maximal recorded travel distances

318 reached $286 \mathrm{~m}\left(\mathrm{~d}_{\mathrm{m}}\right)$ and $278 \mathrm{~m}\left(\mathrm{~d}_{90}\right)$ and the mean distances $100 \mathrm{~m}\left(\mathrm{~d}_{\mathrm{m}}\right)$ and 65

$319 \mathrm{~m}\left(\mathrm{~d}_{90}\right)$. No PIT tagged stone from the top-layer in artificial deposit I and from

320 the bottom-layer of artificial deposit IV was recovered after the flood event.

321 Independent of the artificial deposit, PIT tags located in the bottom layers were

322 transported over the shortest distances. The pass-over loop fixed antenna

323 detected six stones having the origin of artificial deposit I or III (Table 2).

324 [Figure 7]

325 [Figure 8]

326 [Table 2]

\section{Erosion time and average transport velocity}

328 From the six PIT tags equipped stones registered at the pass-over loop fixed 329 antenna only two could be used to calculate the erosion time (Eq. 1-4). Tags

330 with the ID 16 and 364 were not located after the flood pulse (Table 2). ID 271

331 was trapped by a large rock in the river $3 \mathrm{~m}$ downstream of the antenna, and 
332 therefore could not be considered as a representative transported stone. Once

333 the flood passed and the discharge was low, tag ID 325 was registered.

334 However, the stone must have arrived hours before at that location since it was

335 registered at the residual flow of $3.5 \mathrm{~m}^{3} / \mathrm{s}$. It is likely that the antenna did not

336 work properly when stone 325 arrived. Therefore, the analysis was done based

337 on the information of stones with ID $367\left(d_{m}\right)$ and $73\left(d_{90}\right)$. For the analysis of

338 the virtual velocities, values for critical discharge were taken based on the

339 numerical model results (see Table 3). Based on field observations, we

340 considered it not accurate to use these results. The artificial deposits were

341 located after a right river bend causing an increased erosion of artificial deposit I

342 and III (Bathurst et al., 1977; Termini, 2004). We therefore exchanged the

343 values between the artificial deposits (Table 3). The lowest critical discharges

$344\left(29 \mathrm{~m}^{3} / \mathrm{s} d_{m}\right.$ and $\left.84 \mathrm{~m}^{3} / \mathrm{s} d_{90}\right)$ were allocated to artificial deposit III, the second

345 lowest (34 and $106 \mathrm{~m}^{3} / \mathrm{s}$ ) to artificial deposit I, and the highest to artificial

346 deposit II (72 and $137 \mathrm{~m}^{3} / \mathrm{s}$ ). For artificial deposit IV, the average value of the

347 critical discharges from artificial deposit I and II were taken

$348\left(106 / 2+137 / 2=122 \mathrm{~m}^{3} / \mathrm{s}\right)$. The virtual velocity $v_{d}$ resulted in $3.1^{*} 10^{-3} \mathrm{~m} / \mathrm{s}$ for

$349 \operatorname{tag}$ ID $367\left(d_{m}\right)$ and $4.6^{*} 10^{-3} \mathrm{~m} / \mathrm{s}$ for tag ID $73\left(d_{90}\right)$. These two values were then

350 assigned to all 84 tagged stones that were transported further than the lower

351 boundary of the replenishment zone, allowing the calculation of the erosion time

$352 t_{e}$ for each tag (Figure 9). The most effective erosion occurred after the

353 discharge reached $175 \mathrm{~m}^{3} / \mathrm{s}$. Once the discharge passed its maximum and

354 decreased, the erosion diminished quickly and equalled zero once the

355 discharge was below $126 \mathrm{~m}^{3} / \mathrm{s}$. The sedigraph in Figure 9 indicates high erosion

356 mainly when the discharge increased. Four periods of steep increase in 
357 discharge until 12h, intermediated by constant discharge periods, are observed.

358 About $40 \%$ of the stones were transported during these periods of steep

359 increase of the discharge, which represented only $20 \%$ of the water released. If

360 we include the whole rising limb (considering also the constant hydrograph

361 periods), $51 \%$ of the stones were transported. During the constant peak

362 discharge $24 \%$ of the stones were transported and $25 \%$ during the decreasing

363 limb which corresponded to $44 \%$ of the released water. This is associated with

364 an erosion efficiency (eeff) of 2.16 for the steep increase of the discharge, 1.60

365 for the peak discharge and 0.57 for the decreasing limb.

366 [Table 3]

367 [Figure 9]

368 [Table 4]

369 Comparison with laboratory experiments

370 Since the replenishment was not fully eroded (Figure 7), it was compared with

371 an intermediate result of the laboratory tests (Figure 10a). The laboratory

372 experiments lasted until all artificial deposits were eroded. Therefore, the picture

373 taken after $60 \mathrm{~min}$ in the laboratory experiment and corresponding to the field

374 observation was chosen for the OCR and the periodicity analysis (one test took

$375180 \mathrm{~min}$, more information in the supplementary data S6). The laboratory data

376 resulted in a non-stationary periodicity at a normalized distance $x / w$ equal to 2.5

377 with the strongest signal at time step 105 min (Figure 10b). The signal

378 decreases with increasing experiment time. The results of the Sarine have a

379 pronounced peak at $x / w=4.2$ with small signals at shorter distances.

$380 \quad$ [Figure 10] 


\section{Discussion}

\section{Sediment tracking technique}

383 The fixed installed antenna did not work properly during the whole event. Post-

384 flood investigation revealed that the system with the wire in the hose was not

385 rigid enough to resist surface flow velocities of above $2 \mathrm{~m} / \mathrm{s}$. The strong forces

386 and high shear stress acting at the bottom of the Sarine during the flood event

387 changed the shape of the antenna permanently and with it the electromagnetic

388 field. The antenna is tuned for a certain shape and the electromagnetic field

389 around the antenna may decrease and eventually disappear if the antenna-

390 shape changes (Arnaud et al., 2015; Schneider et al., 2010). Despite all the

391 vertically installed metal rods staying in place, the hose was detached from

392 some rods and the cable straps broke, resulting in a high flexibility of the

393 antenna shape. A relatively flexible system as the one used here has the

394 advantage that it tolerates a certain amount of impact by rolling, jumping and

395 sliding rocks, whereas a complete rigid structure may completely break after

396 impact and no data would be collected. Furthermore, if the bed is eroded below

397 the antenna, a flexible system is more tolerant to such processes. The pass-

398 over loop fixed antenna used here demonstrates that despite the high impact,

399 the antenna worked at least partially during the flooding such that six PIT tags

400 could be registered. In total, 36 PIT tag equipped stones were localized with the

401 mobile antenna after the flood downstream of the antenna, but 212 stones

402 remain missing.

403 From the 489 PIT tag equipped stones, 57\% were localized with the

404 mobile antenna. In similar studies, significantly higher recovery rates were 
observed (Hodge et al., 2011; Liébault et al., 2012; Nathan Bradley and Tucker, 2012). There are multiple limitations why the $57 \%$ recovery rate was not higher:

1. The mobile antenna had a detection distance of up to $0.6 \mathrm{~m}$, causing the PIT tags that remained in the mid $(0.5-1 \mathrm{~m})$ or lower layer (ca. $1.5 \mathrm{~m}$ ) of the artificial deposits to be out of the electromagnetic field of the mobile antenna. This also can occur for transported PIT tags which were buried in a lower layer in the river bed. This is probably the most relevant reason for not recovering all tags.

2. PIT tag signal collision (Chapuis et al., 2014). At $134.2 \mathrm{kHz}$, PIT tags do not have an anti-collision protocol. The signal of PIT tags located about $0.3 \mathrm{~m}$ to each other may collide (Cassel et al., 2017a).

3. The size of the tag (32 $\mathrm{mm}$ and $23 \sim \mathrm{mm}$ PIT tags) and the orientation of the PIT tag relative to the antenna influence the detection range (Arnaud et al., 2015, 2017).

4. The deep scour in the bed downstream of the fixed antenna, where the river has a slight bend. In this area, the water depth is more than $4 \mathrm{~m}$ and thus cannot be accessed with the mobile antenna (Figure 7). All tagged stones that settled in this pool could not be located after the flood event.

5. The fact that stones traveled further than the area that was searched with the mobile antenna. After the furthest downstream stone was detected, another 100-m reach was searched with the mobile antenna without detecting any further PIT tags. The dry area on the floodplain, where water passed during the flood event, also was searched for PIT tags. It is likely that there were stones transported significantly further 
downstream. There are 38 PIT tagged stones from artificial deposit I and III that were eroded in the top-layer of artificial deposit I and never found after the event (see Figure 8a). It was likely that they traveled further downstream than the searched area or stopped in the scour as mentioned above.

\section{Erosion time and incipient motion}

436 Considering the deposition map, there is no significant transport of the tagged stones transversal to the flow direction (Figure 7). The PIT tagged stones from artificial deposit I and III settled near the left bank and those from artificial deposit II and IV near the right bank of the river. This indicates that bend-related

440 effects (e.g. secondary currents) are of low importance downstream of the replenishment zone, hence supports the choice of the replenishment zone 442 (Figure 5). The analysis of the erosion time underlies some uncertainties. First, we

444 have the critical discharges for onset of movement. It is not exactly known when

445 the artificial deposits started to erode, since the field observations and the 446 results of the numerical modeling are not concluding. However, the maximum 447 chosen critical discharges reflect the findings of the sediment restoration report 448 of the Sarine. The report concludes that a grain with a characteristic diameter of $44950 \mathrm{~mm}$ moves at a discharge of 70 to $100 \mathrm{~m}^{3} / \mathrm{s}$ and that the armor layer in the 450 residual flow segment of the Sarine breaks up at a discharge of $150 \mathrm{~m}^{3} / \mathrm{s}$ 451 (DAEC, 2014; Jäggi and Hunziker, 2002). Second, most of the PIT tagged stones were disc-shaped and the ratio between the different axes varied

453 significantly in the Zingg diagram (see Figure 3c, Benn and Ballantyne, 1993;

454 Bunte and Abt, 2001; Zingg, 1935). The stone shape has a strong influence on 
455 transport behavior. Differences in particle shape and size favor burial and

456 overlapping due to imbrication of stones when they settle. These effects have

457 been studied in the application of image based surface sampling methods

458 (Graham et al., 2010; Stähly et al., 2017) and contribute to the limited recovery

459 rate. Particles with the same $b$-axis are transported at a significantly smaller

460 discharge when they are disc shaped and not rod-like shaped. The different

461 shapes result also in a large variation of volume and the weight of the tagged

462 stones (see Figure 3a-b). The average weight for a dgo stone is $1700 \mathrm{~g}$, and

463 varied between 720 and $3500 \mathrm{~g}\left(d_{m}: 250 \mathrm{~g}, 110-570 \mathrm{~g}\right)$. The volume of a stone

464 and therefore also its weight, have a key influence on the critical incipient

465 motion of a particle, and a further reason why effective discharge for erosion

466 varies from stone to stone. Since the weight of ID 367 is above average (328 $\mathrm{g}$

467 vs $250 \mathrm{~g} ; d_{m}=57 \mathrm{~mm}$ ) and of ID 73 below average (1202 $\mathrm{g}$ vs $1700 \mathrm{~g} ; d_{90}=$

$468113 \mathrm{~mm}$ ), the erosion curve in Figure 9 could be shifted if measured for stones

469 with different characteristics.

470 Despite these uncertainties of the definition of the erosion time of a

471 tagged stone and differences between laboratory and field conditions, the

472 sedigraph and survivor analysis presented in Figure 9 are in good agreement

473 with observations from the laboratory experiments (Battisacco, 2016) and

474 observations at the Spöl (Robinson, 2012). This may indicate the robustness of

475 the methodology. Leopold et al. (1965) identified that bankful discharge is the

476 effective discharge for morphological change, corresponding to a flood event

477 with a return period of 1.5. Surian et al. (2009) observed a significant change in

478 the geomorphology of side-channel by floods with a return period $<1$ year in the

479 Tagliamento river. During the artificial flood, the surrounding floodplain was 
480 inundated at limited locations and a freeboard of $1 \mathrm{~m}$ was observed at artificial 481 deposits in the Sarine (S7). Therefore, we conclude that the low submergence 482 of artificial deposits was the main reason why artificial deposits were partially 483 eroded. Artificial deposit submergence is a main driver of the erosion of the 484 multi-deposit configuration as revealed in the laboratory results for different 485 hydrographs (Battisacco, 2016). In the laboratory study, complete erosion of the 486 artificial deposits was observed shortly after the peak discharge passed for a 487 right-skewed hydrograph. For a left-skewed hydrograph, meaning the peak of 488 the hydrograph arrives after $50 \%$ of the event time, the erosion or the four 489 artificial deposits may be completed before the peak arrives.

490 Sorting of settling sediment on the surface of the artificial deposits limited 491 the further erosion of the artificial deposits during constant or decreasing 492 discharge during the event (Powell, 1998). This transversal sediment fining is 493 shown in Figure 11. Whenever the discharge was constant for more than one 494 hour (see rising limb), the erosion of tagged sediments from the artificial 495 deposits was low or even zero (at $60 \mathrm{~m}^{3} / \mathrm{s}, 108 \mathrm{~m}^{3} / \mathrm{s}$ and $140 \mathrm{~m}^{3} / \mathrm{s}$ ), what is 496 observed in the sedigraph and the eeff (Figure 9 and Table 4). Therefore, it may 497 be assumed that temporary armor layers formed during the event on the 498 artificial deposits (Parker and Sutherland, 1990). This explains to a certain 499 extent why sediment was not eroded from the residual part of the replenishment 500 once peak discharge passed. In addition to this armoring, the artificial deposits 501 were already partially eroded after the peak passed, resulting in a reduced 502 concentration of flow to the middle of the channel. Hence, the bed shear stress 503 is lower for the same discharge compared to the beginning of the artificial flood 504 event in the replenishment zone. 


\section{Comparison with laboratory experiments}

507 Artificial deposit III was clearly more eroded than the other artificial deposits

508 (Figure 7). This was due to the flow concentration caused by artificial deposit I

509 and II towards the middle of the river. The laboratory study by Battisacco (2016)

510 revealed that erosion started at artificial deposit III (S6). The final situation of the

511 field experiment (Figure 7) was comparable with the resulting state of the

512 laboratory experiments after $60 \mathrm{~min}(S 6)$. After starting at artificial deposit III in

513 the laboratory, it continued at artificial deposit IV, II and I. In the field

514 experiment, however, artificial deposit I was eroded similarly or even more than

515 artificial deposit II and IV. Nevertheless, after $60 \mathrm{~min}$, the two situations were

516 quite similar, with the only difference that artificial deposit IV was less eroded in

517 the field (Figure 7). As observed in the laboratory experiments, erosion also

518 happened in two directions in the Sarine. Lateral erosion occurred along the

519 artificial deposit length and vertical erosion from the top to the bottom of the

520 artificial deposits. This is confirmed by the transport of stones initially placed in

521 the bottom of artificial deposit II and the miss of top-layer stones of artificial

522 deposit I (Figure 8).

523 The field experiment cannot be considered as an exact up-scaling of the

524 laboratory setup. A scaling of the dimensions and positioning of the artificial

525 deposit in the river was normalized to the river width as close as possible to the

526 laboratory study (Table 1). Despite the differences between this prototype and

527 the laboratory experiment, the resulting erosion and deposition patterns are

528 similar. A periodicity was detected in both experiments what may be an

529 indication of the robustness of the approach with the four alternate artificial 
530 deposits. The periodicities at short distances (Figure 10b) are significantly

531 smaller than the detected periodicity at a distance of 4.2 times the river width. In

532 the laboratory results, the replenished sediment spread over a longer

533 normalized distance than in the Sarine (Figure 10a). This can be explained with

534 different boundary conditions such as the heterogeneous geomorphology found

535 in the river, the sediment size, and the hydrograph. Important is the similar

536 development of a distinctive periodicity and not the same location of it.

537 However, the total reach length is about 10 times the river width in the field and

53830 in the laboratory. Therefore, the peak observed in the periodicity of the

539 analyzed river reach may still change, if the analyzed reach length would be

540 similarly to the laboratory, corresponding $900 \mathrm{~m}$ length. The periodicity peak in

541 the river depends largely on the geomorphological structure, in the Sarine this is

542 likely connected with the sinuosity of the river. Furthermore, it must be

543 highlighted that a higher recovery rate of the PIT tagged stones may cause a

544 different periodicity.

\section{Conclusions}

546 For the first time, erosion and deposition processes of a multi-deposit sediment

547 replenishment with four artificial deposits arranged as alternate bars were

548 investigated by stone tracing techniques during an artificially triggered flood in

549 the Sarine River in Switzerland. A similar configuration of the replenishment

550 with four artificial deposits as alternate bars adjacent to the river banks was

551 investigated in laboratory experiments prior to this event, which allowed

552 comparison. The field experiment underlines the laboratory findings in terms of

553 erosion, transport and deposition processes. This sediment replenishment

554 methodology may therefore be an interesting alternative to frequently applied 
555 replenishment techniques (Ock et al., 2013), since the cluster formation in the 556 sediment deposition led to a significant increase in the diversity of aquatic

557 habitats in the restored river reach (Döring et al., 2018; Stähly et al., 2019a).

558 Further, erosion of the material starts at a lower discharge caused by the flow

559 concentration to the river center by geometry. The analysis of the erosion

560 efficiency eeff contributes to the definition of hydrographs of future artificial

561 floods. This knowledge can be transferred to other rivers. Such a combined

562 technique comprising of environmental floods and sediment replenishment may

563 result in a smaller volume of released water, reducing restoration costs.

\section{Acknowledgments}

565 In the framework of their master thesis, Jonas Durand-Gasselin and Anthony

566 Maître contributed to the field work and analysis. Elena Battisacco gave advice

567 in the field work preparations and post-treatment of data and took images.

568 Kevin Gianom, Matthias Thalmann and Diego Tonolla helped during the flood

569 event. Professor Anthony Davison from EPFL provided his expertise for the

570 analysis of the erosion time including survivor analysis. The authorities of the

571 Canton of Fribourg and the hydropower plant operator Groupe e included us in

572 the planning process and financed the artificial deposits. The construction

573 company Brodard Services put into place the sediment deposits. This research

574 project was part of the National Research Programme "Energy Turnaround"

575 (NRP 70, www.nrp70.ch) of the Swiss National Science Foundation (SNSF,

576 Project No. 153972). The first author has a complementary by the Swiss

577 Federal Office of Energy (SFOE, Project No. 501673-01). 
580 Further information concerning this study is given in the supplementary data.

581 The datasets analyzed during the current study are available from the

582 corresponding author on reasonable request.

583

584 Conflict of interests

585 The authors declare no competing interests.

586

\section{References}

588 Allan JD, Castillo MM. 2007. Stream ecology: Structure and function of running

589 waters: Second edition. Springer: Dordrecht, The Netherlands

590 Arnaud F, Piégay H, Béal D, Collery P, Vaudor L, Rollet AJ. 2017. Monitoring

591 gravel augmentation in a large regulated river and implications for process-

592 based restoration. Earth Surface Processes and Landforms 42: 2147-

593 2166.DOI: 10.1002/esp.4161

594 Arnaud F, Piégay H, Vaudor L, Bultingaire L, Fantino G. 2015. Technical

595 specifications of low-frequency radio identification bedload tracking from field

596 experiments: Differences in antennas, tags and operators. Geomorphology 238:

597 37-46.DOI: 10.1016/j.geomorph.2015.02.029

598 Bathurst JC, Thorne CR, Hey RD. 1977. Erratum: Direct measurements of

599 secondary currents in river bends (Nature 269 (504)). Nature 270: 191.DOI:

$60010.1038 / 270191 \mathrm{~d} 0$

601 Battisacco E. 2016. Replenishment of sediment downstream of dams: erosion

602 and transport processes . EPFL Ph.D Thesis No. 7293 and Communication 67 
603 of Laboratory of Hydraulic Constructions (Ed. A. Schleiss), Ecole polytechnique

604 fédérale de Lausanne (EPFL). Lausanne. [online] Available from:

605 https://infoscience.epfl.ch/record/223451/files/EPFL_TH7239.pdf?version=1

606 Battisacco E, Franca MJ, Schleiss AJ. 2016. Sediment replenishment: Influence

607 of the geometrical configuration on the morphological evolution of channel-bed.

608 Water Resources Research 52: 8879-8894.DOI: 10.1002/2016WR019157

609 Benn DI, Ballantyne CK. 1993. The description and representation of particle

610 shape. Earth Surface Processes and Landforms 18: 665-672.DOI:

$611 \quad 10.1002 /$ esp.3290180709

612 Brenna A, Surian N, Mao L. 2019. Virtual Velocity Approach for Estimating Bed

613 Material Transport in Gravel-Bed Rivers: Key Factors and Significance. Water

614 Resources Research 55. DOI: https://doi.org/10.1029/2018WR023556

615 Brousse G, Arnaud-Fassetta G, Liébault F, Bertrand M, Melun G, Loire R,

616 Malavoi JR, Fantino G, Borgniet L. 2019. Channel response to sediment

617 replenishment in a large gravel-bed river: The case of the Saint-Sauveur dam in

618 the Buëch River (Southern Alps, France). River Research and Applications.

619 DOI: https://doi.org/10.1002/rra.3527

620 Bunte K, Abt SR. 2001. Sampling Surface and Subsurface Particle-Size

621 Distributions in Wadable Gravel- and Cobble-Bed Streams for Analyses in

622 Sediment Transport, Hydraulics, and Streambed Monitoring. 0 : 450. DOI:

$623 \quad 10.1017 /$ CBO9781107415324.004

624 Cassel M, Dépret T, Piégay H. 2017a. Assessment of a new solution for

625 tracking pebbles in rivers based on active RFID. Earth Surface Processes and 
627 Cassel M, Piégay H, Lavé J. 2017b. Effects of transport and insertion of radio

628 frequency identification (RFID) transponders on resistance and shape of natural

629 and synthetic pebbles: applications for riverine and coastal bedload tracking.

630 Earth Surface Processes and Landforms 42: 399-413.DOI: 10.1002/esp.3989

631 Chapuis M, Bright CJ, Hufnagel J, Macvicar B. 2014. Detection ranges and 632 uncertainty of passive Radio Frequency Identification (RFID) transponders for 633 sediment tracking in gravel rivers and coastal environments. Earth Surface

634 Processes and Landforms 39: 2109-2120.DOI: 10.1002/esp.3620

635 Cross WF, Baxter C V., Donner KC, Rosi-Marshall EJ, Kennedy TA, Hall RO,

636 Wellard Kelly HA, Rogers RS. 2011. Ecosystem ecology meets adaptive

637 management: Food web response to a controlled flood on the Colorado River,

638 Glen Canyon. Ecological Applications 21: 2016-2033.DOI: 10.1890/10-1719.1

639 Cui Y, Parker G, Lisle TE, Gott J, Hansler-Ball ME, Pizzuto JE, Allmendinger

$640 \mathrm{NE}$, Reed JM. 2003. Sediment pulses in mountain rivers: 1. Experiments. Water

641 Resources Research 39DOI: 10.1029/2002WR001803

642 DAEC. 2014. Planification de l'assainissement du charriage - Rapport final .

643 Fribourg

644 Davison AC, Hinkley D V. 1997. Bootstrap Methods and their Application.

645 Cambridge University Press: New York, USA [online] Available from:

646 http://www.jstor.org/stable/1271471?origin=crossref

647 Döring M, Tonolla D, Robinson CT, Schleiss AJ, Stähly S, Gufler C, Geilhausen 
648 M, Di Cugno N. 2018. Künstliches Hochwasser an der Saane - Eine

649 Massnahme zum nachhaltigen Auenmanagement [in german]. Wasser Energie

650 Luft 2: 119-127. [online] Available from:

651 https://infoscience.epfl.ch/record/255687/files/2018-1203

652 Döring_Tonolla_Robinson_Schleiss_Stähly_Gufler_Geilhausen_DiCugno

653 Künstliches Hochwasser an der Saane.pdf

654 Fehr R. 1987. Geschiebeanalysen in Gebirgsflüssen, Mitteilungen der

655 Versuchsanstalt für Wasserbau, Hydrologie und Glaziologie Nr. 92 (Ed. D.

656 Vischer). Swiss Federal Institute of Technology (ETH) Zurich, Switzerland

657 Friedl F, Weitbrecht V, Boes RM. 2018. Erosion pattern of artificial gravel

658 deposits. International Journal of Sediment Research 33: 57-67.DOI:

$65910.1016 / j . j \mathrm{ijsrc} .2017 .08 .003$

660 Gaeuman D. 2012. Mitigating Downstream Effects of Dams. In Gravel-Bed

661 Rivers: Processes, Tools, Environments, Church M, Biron PM, and Roy AG

662 (eds). John Wiley \& Sons Ltd.; 182-189.

663 Gaeuman D, Stewart R, Schmandt B, Pryor C. 2017. Geomorphic response to

664 gravel augmentation and high-flow dam release in the Trinity River, California.

665 Earth Surface Processes and Landforms 42: 2523-2540.DOI:

$666 \quad 10.1002 /$ esp.4191

667 Graham DJ, Rollet AJ, Piégay H, Rice SP. 2010. Maximizing the accuracy of

668 image-based surface sediment sampling techniques. Water Resources

669 Research 46DOI: 10.1029/2008WR006940

670 Hassan MA, Church M, Schick AP. 1991. Distance of movement of coarse 
671 particles in gravel bed streams. Water Resources Research 27: 503-511.DOI:

$672 \quad 10.1029 / 90$ WR02762

673 Hassan MA, Roy AG. 2016. Coarse particle tracing in fluvial geomorphology. In

674 Tools in Fluvial Geomorphology, Kondolf GM and Piégay H (eds). Wiley-

675 Blackwell; 306-323.

676 Hassan MA, Zimmermann AE. 2012. Channel Response and Recovery to

677 Changes in Sediment Supply. In Gravel-Bed Rivers: Processes, Tools,

678 Environments, Church M, Biron PM, and Roy AG (eds). John Wiley \& Sons

679 Ltd.; 464-473.

680 Heckmann T, Haas F, Abel J, Rimböck A, Becht M. 2017. Feeding the hungry

681 river: Fluvial morphodynamics and the entrainment of artificially inserted

682 sediment at the dammed river Isar, Eastern Alps, Germany. Geomorphology

683 291: 128-142.DOI: 10.1016/j.geomorph.2017.01.025

684 Hodge RA, Hoey TB, Sklar LS. 2011. Bed load transport in bedrock rivers: The 685 role of sediment cover in grain entrainment, translation, and deposition. Journal 686 of Geophysical Research: Earth Surface 116DOI: 10.1029/2011JF002032

687 Jäggi M, Hunziker R. 2002. Petite-Sarine - Etude sur l'incidence du barrage de 688 Rossens sur la morphologie fluviale, le charriage et l'évolution future de cette 689 zone alluviale. Fribourg

690 Juez C, Battisacco E, Schleiss AJ, Franca MJ. 2016. Assessment of the

691 performance of numerical modeling in reproducing a replenishment of

692 sediments in a water-worked channel. Advances in Water Resources 92: 10-

693 22.DOI: 10.1016/j.advwatres.2016.03.010 
694 Kantoush SA, Schleiss AJ. 2009. Channel formation during flushing of large

695 shallow reservoirs with different geometries. Environmental Technology 30:

696 855-863.DOI: 10.1080/09593330902990162

697 Kondolf GM. 1997. HungryWater: Effects of Dams and Gravel Mining on River

698 Channels. Environmental Management 21(4) : 533-551.

699 Kondolf GM, Wilcock PR. 1996. The flushing flow problem: Defining and

700 evaluating objectives. Water Resources Research 32: 2589-2599.DOI:

$701 \quad 10.1029 / 96$ WR00898

702 Konrad CP, Olden JD, Lyte DA, Melis TS, Schmidt JC, Bray EN, Freeman MC,

703 Gido KB, Hemphill NP, Kennard MJ, McMullen LE, Mims MC, Pyron MP,

704 Robinson CT, Williams JG. 2011. Large-scale Flow Experiments for Managing

705 River Systems. BioScience 61: 948-959.DOI: 10.1525/bio.2011.61.12.5 [online]

706 Available from: https://academic.oup.com/bioscience/article-

707 lookup/doi/10.1525/bio.2011.61.12.5

708 Lamarre H, MacVicar B, Roy AG. 2005. Using Passive Integrated Transponder

709 (PIT) Tags to Investigate Sediment Transport in Gravel-Bed Rivers. Journal of

710 Sedimentary Research 75: 736-741.DOI: 10.2110/jsr.2005.059 [online]

711 Available from: http://jsedres.sepmonline.org/cgi/doi/10.2110/jsr.2005.059

712 Lamarre H, Roy AG. 2008. The role of morphology on the displacement of

713 particles in a step-pool river system. Geomorphology 99: 270-279.DOI:

714 10.1016/j.geomorph.2007.11.005

715 Leopold LB, Wolman MG, Miller JP. 1965. Fluvial processes in geomorphology.

716 Journal of Hydrology 3: 342.DOI: 10.1016/0022-1694(65)90101-0 
717 Liébault F, Bellot H, Chapuis M, Klotz S, Deschâtres M. 2012. Bedload tracing

718 in a high-sediment-load mountain stream. Earth Surface Processes and

719 Landforms 37: 385-399.DOI: 10.1002/esp.2245

720 Loire R, Grosprêtre L, Malavoi J-R, Ortiz O, Piégay H. 2019. What Discharge Is

721 Required to Remove Silt and Sand Downstream from a Dam? An Adaptive

722 Approach on the Selves River, France. Water 11: 392.DOI: 10.3390/w11020392

723 [online] Available from: http://www.mdpi.com/2073-4441/11/2/392

724 MacVicar BJ, Roy AG. 2011. Sediment mobility in a forced riffle-pool.

725 Geomorphology 125: 445-456.DOI: 10.1016/j.geomorph.2010.10.031

726 Magilligan FJ, Nislow KH. 2005. Changes in hydrologic regime by dams.

727 Geomorphology 71: 61-78.DOI: 10.1016/j.geomorph.2004.08.017

728 Meyer-Peter E, Müller R. 1948. Formulas for Bed-Load Transport. Proceedings

729 of the 2nd Meeting of the International Association of Hydraulic Research : 39-

730 64. DOI: 1948-06-07

731 Milani G, Volpi M, Tonolla D, Doering M, Robinson C, Kneubühler M,

732 Schaepman M. 2018. Robust quantification of riverine land cover dynamics by

733 high-resolution remote sensing. Remote Sensing of Environment 217: 491-

734 505.DOI: 10.1016/j.rse.2018.08.035

735 Moyle PB, Mount JF. 2007. Homogenous rivers, homogenous faunas.

736 Proceedings of the National Academy of Sciences 104: 5711-5712.DOI:

737 10.1073/pnas.0701457104 [online] Available from:

738 http://www.pnas.org/cgi/doi/10.1073/pnas.0701457104 
739 Nathan Bradley D, Tucker GE. 2012. Measuring gravel transport and dispersion

740 in a mountain river using passive radio tracers. Earth Surface Processes and

741 Landforms 37: 1034-1045.DOI: 10.1002/esp.3223

742 Ock G, Sumi T, Takemon Y. 2013. Sediment replenishment to downstream

743 reaches below dams: implementation perspectives. Hydrological Research

744 Letters 7: 54-59.DOI: 10.3178/hrl.7.54 [online] Available from:

745 http://jlc.jst.go.jp/DN/JST.JSTAGE/hrl/7.54?lang=en\&from=CrossRef\&type=abst

746 ract

747 Olinde L, Johnson JPL. 2015. Using RFID and accelerometer-embedded

748 tracers to measure probabilities of bed load transport, step lengths, and rest

749 times in a mountain stream. Water Resources Research 51: 7572-7589.DOI:

$750 \quad 10.1002 / 2014$ WR016120

751 Parker G. 1990. Surface-based bedload transport relation for gravel rivers.

752 Journal of Hydraulic Research 28: 417-436.DOI: 10.1080/00221689009499058

753 [online] Available from:

754 http://www.tandfonline.com/doi/abs/10.1080/00221689009499058

755 Parker G, Sutherland AJ. 1990. Fluvial armor. Journal of Hydraulic Research

756 28: 529-544.DOI: 10.1080/00221689009499044 [online] Available from:

757 http://www.tandfonline.com/doi/abs/10.1080/00221689009499044

758 Poff NL, Allan JD, Bain MB, Karr JR, Prestegaard KL, Richter BD, Sparks RE,

759 Stromberg JC. 1997. The Natural Flow Regime. BioScience 47: 769-784.DOI:

$76010.2307 / 1313099$ [online] Available from:

761 https://academic.oup.com/bioscience/article-lookup/doi/10.2307/1313099 
762 Poff NLR, Schmidt JC. 2016. How dams can go with the flow. Science 353:

763 1099-1100.DOI: 10.1126/science.aah4926

764 Powell DM. 1998. Patterns and Processes of Sediment Sorting in Gravel-Bed

765 Rivers. Progress in Physical Geography 22: 1-32. [online] Available from:

766 isi:000072994000001

767 Robinson CT. 2012. Long-term changes in community assembly, resistance,

768 and resilience following experimental floods. Ecological applications : a

769 publication of the Ecological Society of America 22: 1949-1961.DOI:

$77010.1890 / 11-1042.1$ [online] Available from:

771 http://www.ncbi.nlm.nih.gov/pubmed/23210311

772 Robinson CT, Siebers AR, Ortlepp J. 2018. Long-term ecological responses of

773 the River Spöl to experimental floods. Freshwater Science : 433-447. DOI:

$77410.1086 / 699481$ [online] Available from:

775 https://www.journals.uchicago.edu/doi/10.1086/699481

776 Robinson CT, Uehlinger U. 2008. Experimental floods cause ecosystem regime

777 shift in a regulated river. Ecological Applications 18: 511-526.DOI: 10.1890/07-

$778 \quad 0886.1$

779 Schleiss AJ, Franca MJ, Juez C, De Cesare G. 2016. Reservoir sedimentation.

780 Journal of Hydraulic Research 54: 595-614.DOI:

$781 \quad 10.1080 / 00221686.2016 .1225320$

782 Schneider J, Hegglin R, Meier S, Turowski JM, Nitsche M, Rickenmann D.

783 2010. Studying sediment transport in mountain rivers by mobile and stationary

784 RFID antennas. River Flow : 1723-1730. [online] Available from: 
785 http://www.wsl.ch/wsl/info/mitarbeitende/turowski/pdf/10748.pdf\%5Cnpapers3://

786 publication/uuid/51383AF6-AB28-4756-A250-BDB40F9E15D0

787 Sklar LS, Fadde J, Venditti JG, Nelson P, Aleksandra Wydzga M, Cui Y,

788 Dietrich WE. 2009. Translation and dispersion of sediment pulses in flume

789 experiments simulating gravel augmentation below dams. Water Resources

790 Research 45DOI: 10.1029/2008WR007346

791 Slaven S, Slaven I, Anders AM. 2014. New Gripping and Binding Device

792 Greatly Improves Preparation of Natural Clasts for RFID Tracking. Journal of

793 Hydraulic Engineering 140: 6014017.DOI: 10.1061/(ASCE)HY.1943-

7947900.0000943 [online] Available from:

795 http://ascelibrary.org/doi/10.1061/\%28ASCE\%29HY.1943-7900.0000943

796 Sparks RE. 1995. Need for Ecosystem Management of Large Rivers and Their

797 Floodplains. BioScience 45: 168-182.DOI: 10.2307/1312556 [online] Available 798 from:

799 http://www.jstor.org/stable/1312556\%0Ahttp://about.jstor.org/terms\%0Ahttps://a

800 cademic.oup.com/bioscience/article-lookup/doi/10.2307/1312556

801 Stähly S, Franca MJ, Robinson CT, Schleiss AJ. 2019a. Sediment

802 replenishment combined with an artificial flood improves river habitats

803 downstream of a dam. Scientific Reports 9(1), 5176. DOI: 10.1038/s41598-019-

$804 \quad 41575-6$

805 Stähly S, Friedrich H, Detert M. 2017. Size Ratio of Fluvial Grains' Intermediate

806 Axes Assessed by Image Processing and Square-Hole Sieving. Journal of

807 Hydraulic Engineering 143: 6017005.DOI: 10.1061/(ASCE)HY.1943- 
809 Stähly S, Gostner W, Franca MJ, Christopher T, Schleiss AJ. 2019b. Sampling

810 sufficiency for determining hydraulic habitat diversity. Journal of Ecohydraulics :

811 [accepted for publication]. DOI: 10.1080/24705357.2019.1576021

812 Stähly S, Maître A, Franca MJ, Robinson CT, Schleiss AJ. 2018. Experiments

813 with sediment replenishment in a residual flow reach: Comparison of field

814 datawith laboratory experiments. $9^{\text {th }}$ International conference on fluvial

815 hydraulics River Flow 2018,18.-20. September 2018, Lyon, France, pages

816 02022. DOI: $10.1051 / \mathrm{e} 3 s c o n f / 20184002022$

817 Stoica P, Moses RL, Hall P. 2005. Introduction to Spectral Analysis.

818 Technometrics 47: 104-105.DOI: 10.1198/tech.2005.s841

819 Surian N, Mao L, Giacomin M, Ziliani L. 2009. Morphological effects of different

820 channel-forming discharges in a gravel-bed river. Earth Surface Processes and

821 Landforms 34: 1093-1107.DOI: 10.1002/esp.1798

822 Termini D. 2004. Flow in meandering bends. In River Flow 2004: Proceedings

823 of the Second International Conference on Fluvial Hydraulics, Greco,

824 Carravetta, and Della Morte (eds). Taylor \& Francis Group, London; 109-117.

825 Warner RF. 2012. Environmental impacts of hydroelectric power and other

826 anthropogenic developments on the hydromorphology and ecology of the

827 Durance channel and the Etang de Berre, southeast France. Journal of

828 Environmental Management 104: 35-50.DOI: 10.1016/j.jenvman.2012.03.011

829 Wilcock PR, Kondolf GM, Matthews WVG, Barta AF. 1996. Specification of 
830 sediment maintenance flows for a large gravel-bed river. Water Resources

831 Research 32: 2911-2921.DOI: 10.1029/96WR01627

832 Wohl E, Bledsoe BP, Jacobson RB, Poff NL, Rathburn SL, Walters DM, Wilcox 833 AC. 2015. The natural sediment regime in rivers: Broadening the foundation for 834 ecosystem management. BioScience 65: 358-371.DOI: 10.1093/biosci/biv002

835 Zingg T. 1935. Beitrag zur Schotteranalyse. Schweizerische Mineralogisch-

836 Petrographische Mitteilungen 15: 39-140.DOI: https://doi.org/10.3929/ethz-a-

837010180262 Rights [online] Available from: https://www.research-

838 collection.ethz.ch/bitstream/handle/20.500.11850/135183/eth-21472-02.pdf

839

840 
841 Table 1. Characteristics of the laboratory and field replenishment experiments.

Parameter Unit Laboratory Field

\begin{tabular}{llll}
\hline Mean channel slope & {$[-]$} & $1.5 \%$ & $0.3 \%$
\end{tabular}

$\begin{array}{llll}\text { Hydrograph peak discharge } Q & {\left[\mathrm{~m}^{3} / \mathrm{s}\right]} & 0.031 & 195\end{array}$

Hydrograph skewness $\quad[-] \quad$ highly left-skewed slightly right skewed

$\begin{array}{llll}\text { Channel-bed width } B & {[\mathrm{~m}]} & 0.40 & 30\end{array}$

$\begin{array}{llll}\text { Channel-bed width at peak } & {[\mathrm{m}]} & 0.46 & 35\end{array}$

discharge

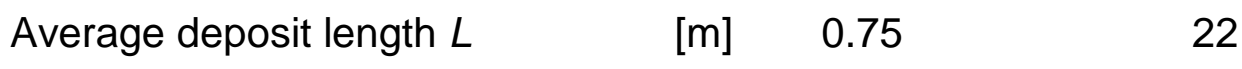

$\begin{array}{llll}\text { Average deposit width } W & {[\mathrm{~m}]} & 0.13 & 8\end{array}$

$\begin{array}{llll}\text { Average deposit height } H & \text { [m] } & 0.07 & 1.5^{*}\end{array}$

$\begin{array}{llll}\text { Total replenishment volume } & {\left[\mathrm{m}^{3}\right]} & 0.028 & 1000\end{array}$

$90 \%$-quantile of the diameter $d_{90} \quad[\mathrm{~mm}] \quad 6.95 \quad 113$

$\begin{array}{llll}\text { Dominant diameter } d_{m} & {[\mathrm{~mm}]} & 4.89 & 57\end{array}$

$\begin{array}{llll}\text { Ratio } d_{90} / d_{m} & {[-]} & 1.42 & 1.98\end{array}$

$842{ }^{*}$ The average deposit height in the field experiment was not constant. 
843 Table 2. Information about the six stones detected with the field loop antenna.

844 bot $=$ bottom level; mid = middle level; top $=$ top level of initial placement in the

845 artificial deposit of origin. $\mathrm{NaN}$ as a result of the further travel distance $\left(X_{\sigma}+X_{a}\right)$

846 indicates that the tagged stone was not located after the flood event. The

847 detection time refers to on-site time on 14 September 2016 except for tag ID

848325 recorded on the following day.

\begin{tabular}{|c|c|c|c|c|c|c|c|}
\hline Tag ID & & 16 & 271 & 367 & 73 & 364 & 325 \\
\hline Deposit of origin & {$[-]$} & III & I & III & III & III & 1 \\
\hline Level placed & {$[-]$} & mid & bot & mid & top & mid & mid \\
\hline Type & {$[-]$} & d90 & $d_{m}$ & $d_{m}$ & $d_{90}$ & $d_{m}$ & $d_{m}$ \\
\hline Tag size & {$[\mathrm{mm}]$} & 32 & 32 & 23 & 32 & 23 & 23 \\
\hline Diameter (b-axis) & [mm] & 122 & 58 & 55 & 117 & 56 & 59 \\
\hline Stone shape & {$[-]$} & $\begin{array}{l}\text { disc- } \\
\text { shaped }\end{array}$ & $\begin{array}{l}\text { rod- } \\
\text { like }\end{array}$ & spherical & $\begin{array}{l}\text { rod- } \\
\text { like }\end{array}$ & $\begin{array}{l}\text { disc- } \\
\text { shaped }\end{array}$ & spherical \\
\hline Weight & [g] & 2251 & 236 & 328 & 1202 & 361 & 299 \\
\hline Detection time & [hh:mm] & $18: 25$ & 19:37 & $19: 39$ & $19: 44$ & 19:53 & $\begin{array}{l}10: 11 \\
(+1)\end{array}$ \\
\hline Detection duration & [s] & 33 & 4 & 0.9 & 145 & 9.1 & 79 \\
\hline Further transport $\left(\mathrm{X}_{\mathrm{d}}-\mathrm{X}_{\mathrm{a}}\right)$ & {$[\mathrm{m}]$} & $\mathrm{NaN}$ & 3 & 88 & 87 & $\mathrm{NaN}$ & 0 \\
\hline
\end{tabular}

849 
850 Table 3. Critical discharges taken for the estimation of virtual velocity and 851 erosion time. Values used for the calculation were chosen based on the 852 numerical model results and field observations. As a deposition criterion, the 853 smallest discharge taken for the incipient erosion was used for each artificial 854 deposit.

855

\begin{tabular}{l|cc|cc|ccc}
\hline & \multicolumn{3}{|c|}{ Incipient motion Q } & \multicolumn{3}{c}{ Deposition Q } \\
& Model results & \multicolumn{4}{c}{ Used values } \\
& $\mathrm{d}_{\mathrm{m}}$ & $\mathrm{d}_{90}$ & $\mathrm{~d}_{\mathrm{m}}$ & $\mathrm{d}_{90}$ & $\mathrm{~d}_{\mathrm{m}}$ & $\mathrm{d}_{90}$ \\
& {$\left[\mathrm{~m}^{3} / \mathrm{s}\right]$} & {$\left[\mathrm{m}^{3} / \mathrm{s}\right]$} & {$\left[\mathrm{m}^{3} / \mathrm{s}\right]$} & {$\left[\mathrm{m}^{3} / \mathrm{s}\right]$} & {$\left[\mathrm{m}^{3} / \mathrm{s}\right]$} & {$\left[\mathrm{m}^{3} / \mathrm{s}\right]$} \\
\hline Deposit I & 72 & 137 & 34 & 106 & 84 & 29 \\
Deposit II & 72 & 106 & 72 & 137 & 84 & 29 \\
Deposit & 34 & 106 & 29 & 84 & 84 & 29 \\
III & & & & & & \\
Deposit & 29 & 84 & 53 & 122 & 84 & 29 \\
IV & & & & & & \\
\hline
\end{tabular}


857 Table 4. Erosion efficiency (eeff), hydrograph information as well as 858 interpretation of the sedigraph and Figure 9.

\begin{tabular}{|c|c|c|c|c|c|c|}
\hline & \multicolumn{2}{|c|}{ Eroded stones } & \multirow{2}{*}{$\begin{array}{l}\text { Period } \\
\text { [hh:mm] }\end{array}$} & \multicolumn{2}{|c|}{$\begin{array}{c}\text { Released water } \\
\text { volume }\end{array}$} & \multirow{2}{*}{$\begin{array}{l}\text { eeff } \\
{[-]}\end{array}$} \\
\hline & [\%] & [Number of tags] & & [mio $\mathrm{m}^{3}$ ] & [\%] & \\
\hline $\begin{array}{l}\text { Steep increasing } \\
\text { periods }\end{array}$ & 41 & 34 & $06: 30$ & 1.79 & 19 & 2.16 \\
\hline Increasing limb & 51 & 43 & $10: 30$ & 3.79 & 41 & 1.24 \\
\hline $\begin{array}{l}\text { Constant peak } \\
\text { discharge }\end{array}$ & 24 & 20 & 02:00 & 1.40 & 15 & 1.60 \\
\hline Decreasing limb & 25 & 21 & $15: 30$ & 4.07 & 44 & 0.57 \\
\hline Total & 100 & 84 & $28: 00$ & 9.26 & 100 & 1.00 \\
\hline
\end{tabular}




\section{Erosion, transport and deposition of a sediment replenishment under flood conditions}

Survey of the combination of sediment replenishment with an

artificial flood as a measure to increase habitat suitability

Severin Stähly ${ }^{a *}$, Mário J. Franca ${ }^{b, c}$, Christopher T. Robinson ${ }^{d}$ and Anton J. Schleiss ${ }^{a}$

aLaboratoire de Constructions Hydrauliques (LCH), École Polytechnique Fédérale de Lausanne (EPFL), Lausanne, Switzerland; bIHE Delft Institute for Water Education, Delft, The Netherlands; 'Department of Hydraulic Engineering, Delft University of Technology, Delft, The Netherlands; ' ${ }^{\text {Aquatic }}$ Ecology Department, Swiss Federal Institute of Aquatic Science and Technology (EAWAG), Dübendorf, Switzerland

*corresponding author: Laboratoire de Constructions Hydrauliques (LCH), École Polytechnique Fédérale de Lausanne (EFPL), Switzerland. +41-77-2225525. E-mail: sev.staehly@gmail.com.

24.07.2020 


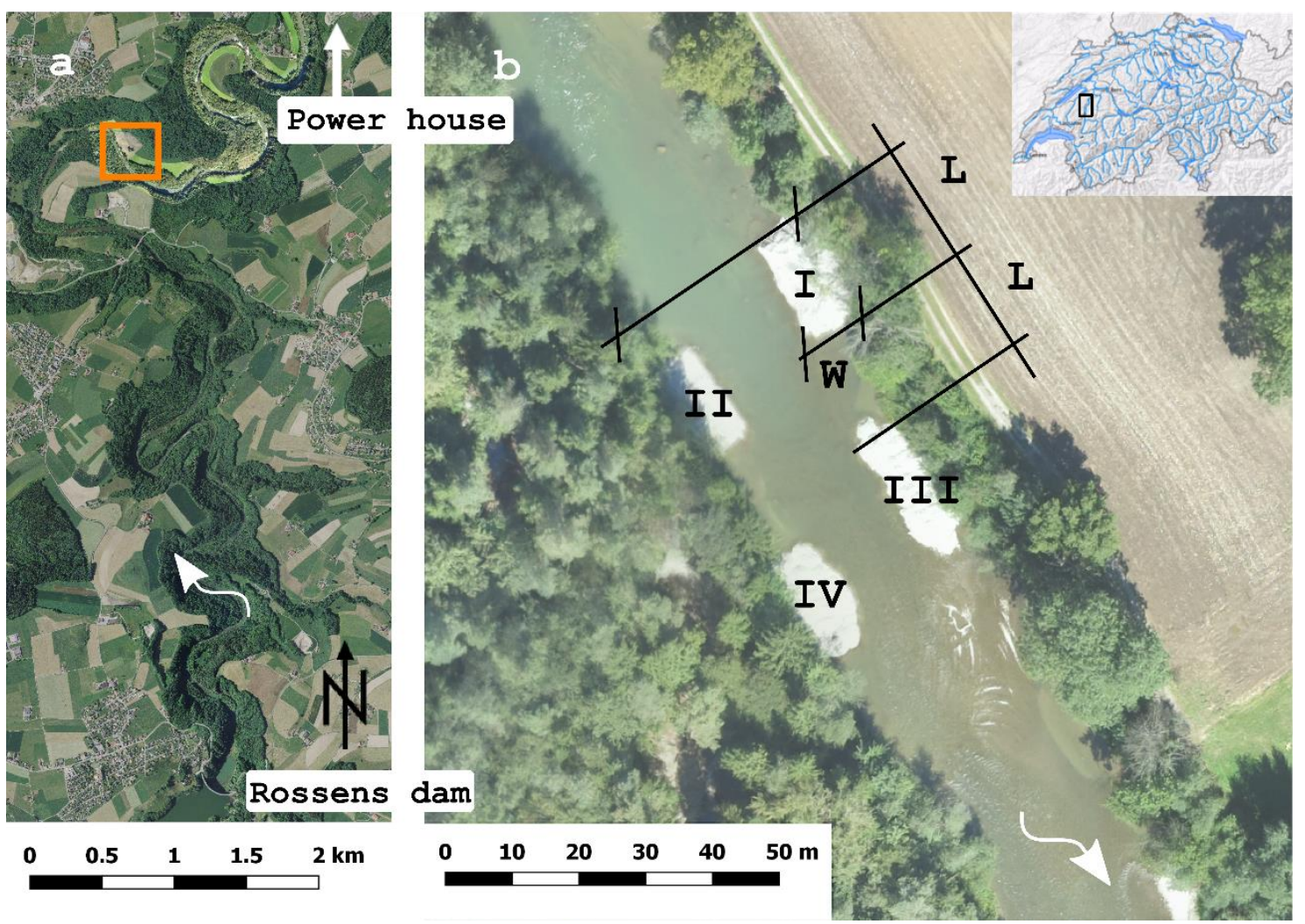

Figure 1. (a) Location of the sediment replenishment. (b) Configuration of the four artificial sediment deposits in the Sarine river, indicated with the orange square in a. The distance between the artificial deposits was about a deposit length $L$, the shift between the artificial deposits on the left and the right bank is half a deposit length. The height of the artificial deposits was about $1.5 \mathrm{~m}$ above the initial river-bed. $W$ is the deposit width. The numbering refers to the name of the artificial deposits from upstream to downstream: artificial deposit I, II, III and IV. Geodata (C) Swisstopo (left) and Research unit Ecohydrology, ZHAW (right). 


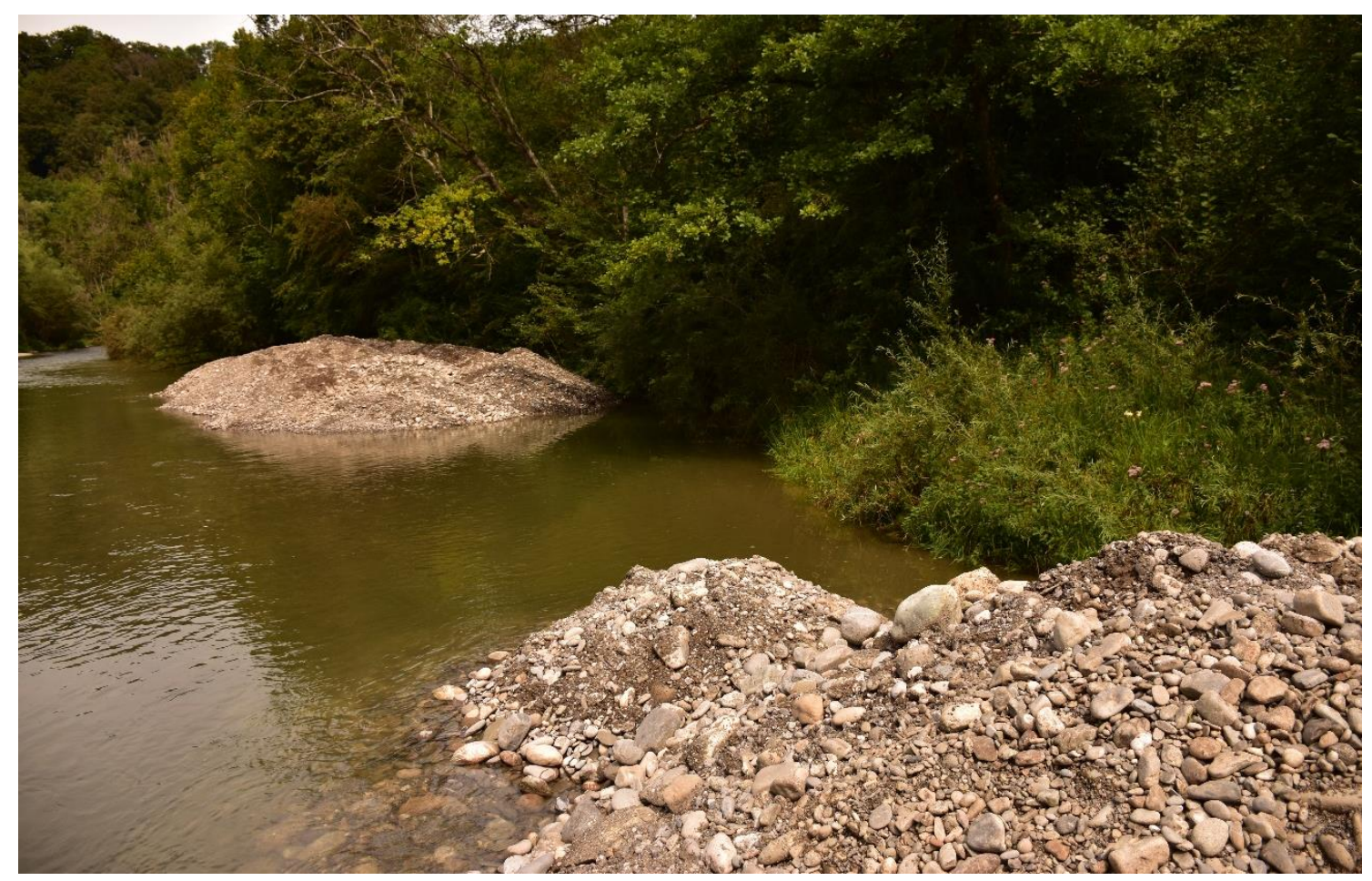

Figure 2. View from artificial deposit III upstream towards artificial deposit I at the day of installation. The replenished sediment was directly excavated from the adjacent floodplain without sorting. Image: Elena Battisacco. 

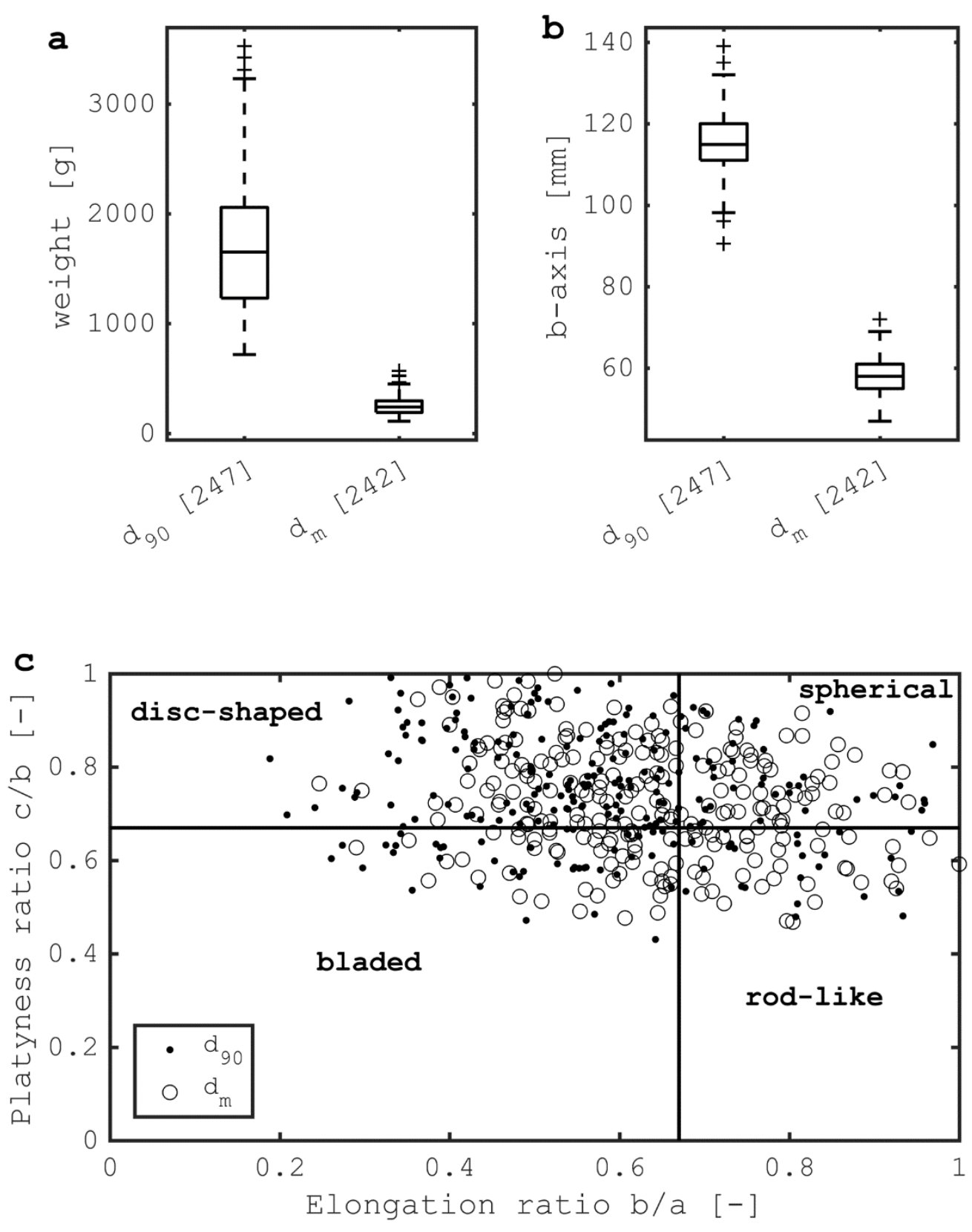

Figure 3. Physical properties of the stones equipped with RFID PIT tags. (a) Weight distribution; (b) b-axis distribution; (c) shape classification after Zingg (1935); most stones were disc-shaped. 


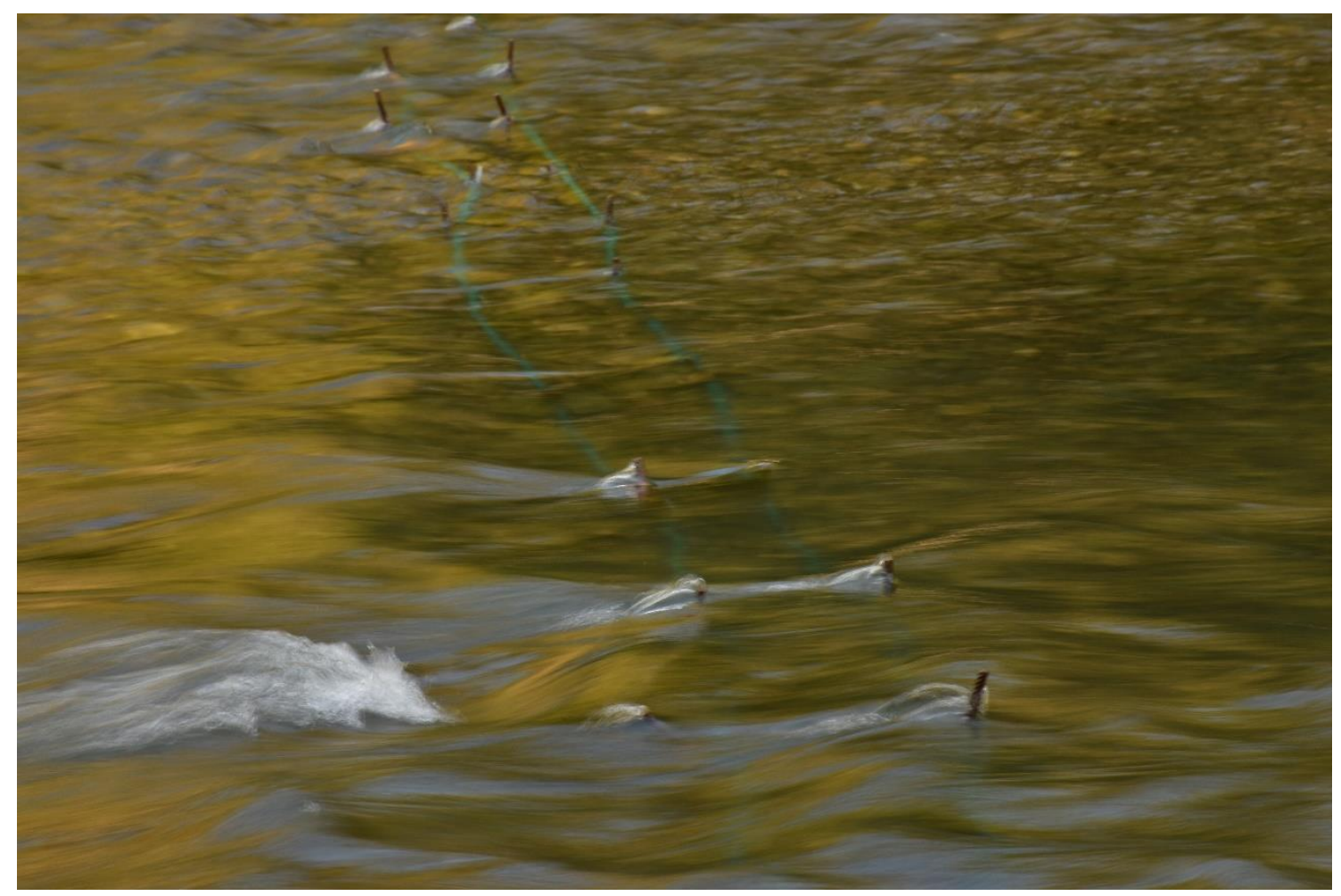

Figure 4. Installed pass-over loop fixed-antenna in the Sarine river. The single loop cable was installed for protection inside a garden hose. The hose was fixed with cable straps to 1 -m long vertical armoring irons installed in the river bed every meter. The antenna had a surface of $25 \times 0.3 \mathrm{~m}^{2}$. Image: Elena Battisacco.

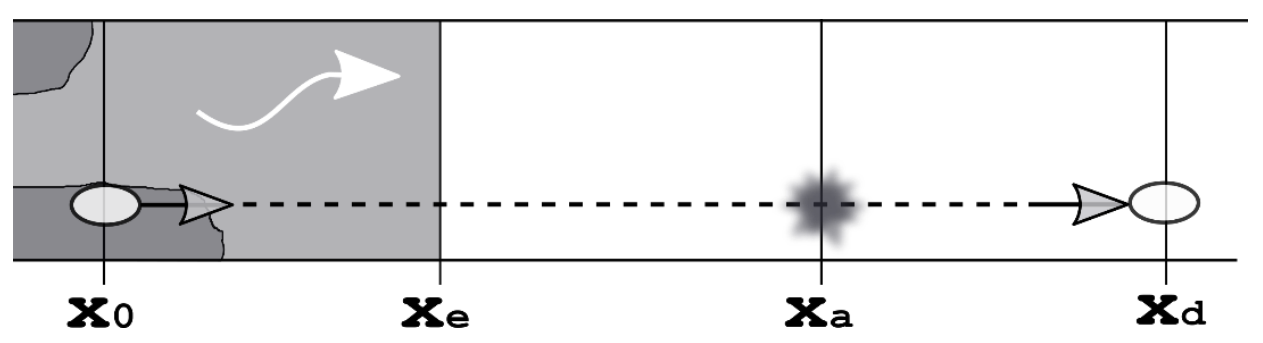

Figure 5. Concept and sketch of the longitudinal scales. The replenishment zone is shaded, artificial deposit III and IV dark grey. $x_{0}=$ original position where a tagged stone was put in the artificial sediment deposit; $x_{e}=$ downstream end of the replenishment zone; $x_{a}=$ location of the pass-over loop fix-antenna; $x_{d}=$ final position where a tagged stone was found after the flood event with the mobile antenna. 


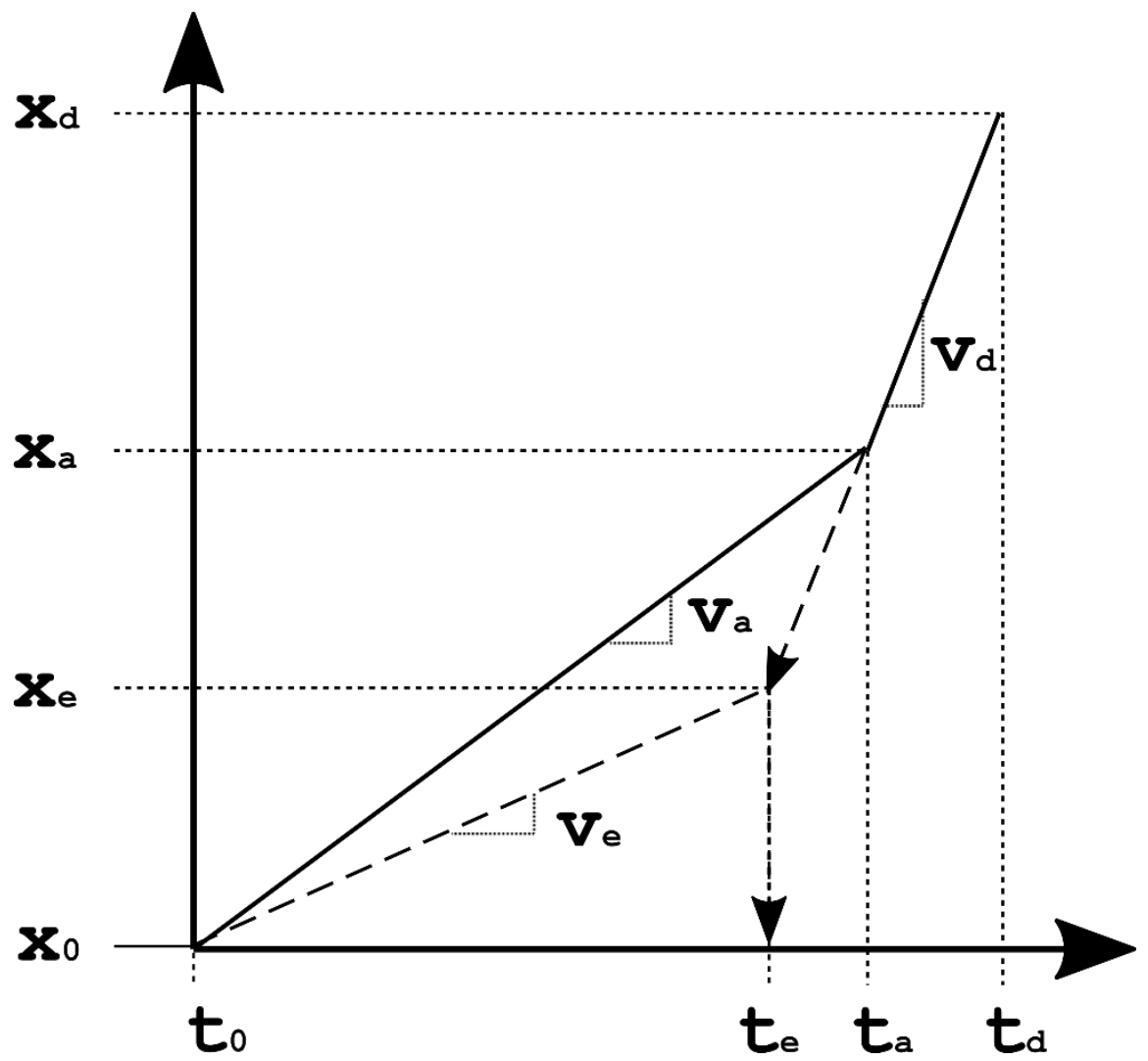

Figure 6. Concept of the estimation of the average sediment transport velocity or virtual velocity $\left(v_{d}\right)$ and erosion velocity $\left(v_{e}\right) . x_{0}=$ original position where a tagged stone was put in the artificial sediment deposit; $x_{e}=$ downstream end of the replenishment zone; $x_{a}=$ location of the pass-over loop fixed-antenna; $x_{d}=$ final position where a tagged stone was found after the flood event. $t_{0}=$ time of erosion; $t_{e}=$ time of leaving the replenishment zone; $t_{a}=$ time of passing the pass-over loop fixed-antenna; $t_{d}=$ time the stone stopped moving. 


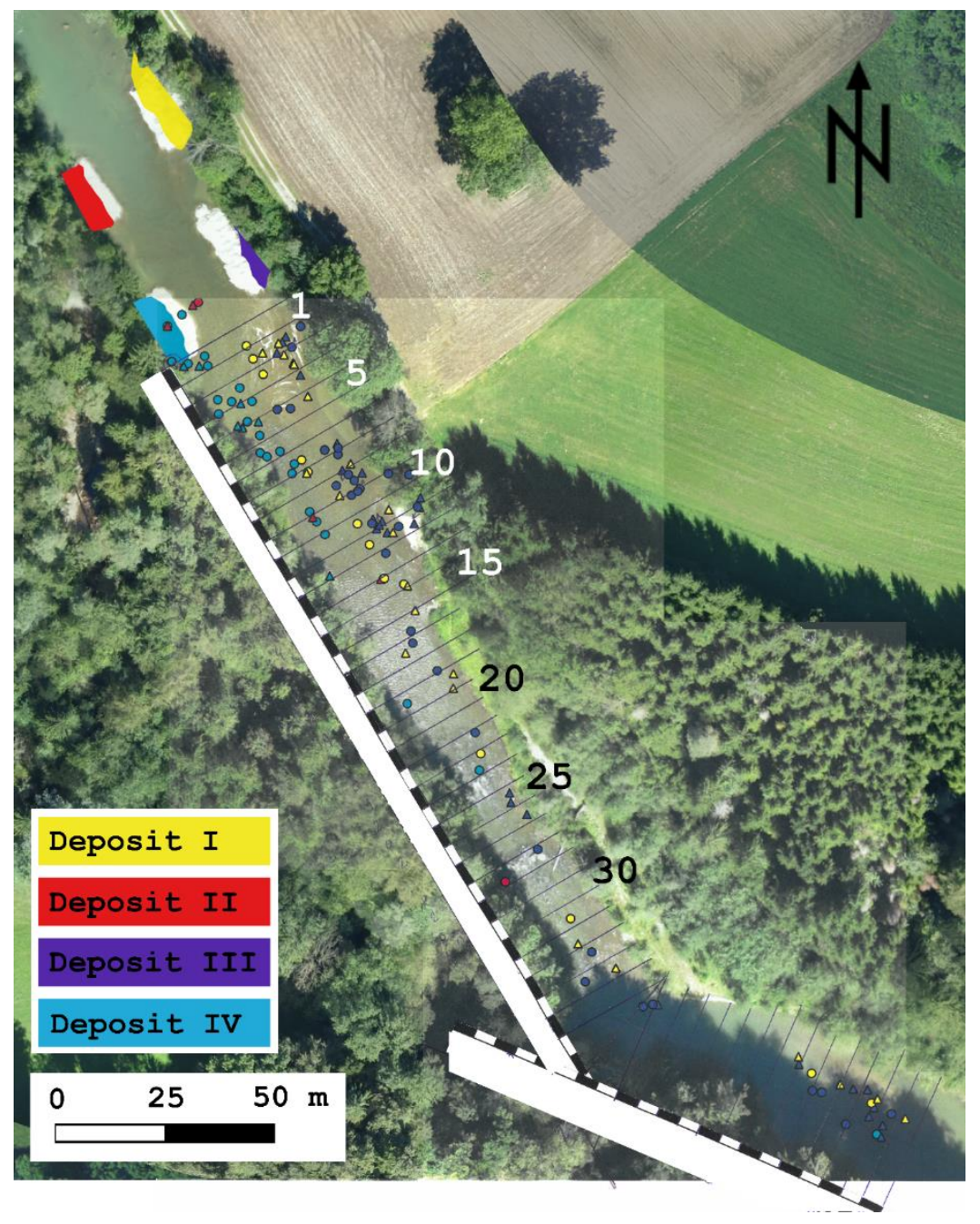

Figure 7. Field sketch: The exposed dry surface of the four artificial deposits before (air-image background) and after (colored areas) the artificial flood event. The residual flow discharge was $3.5 \mathrm{~m}^{3} / \mathrm{s}$ when the air-image was taken before the flood event and $2.5 \mathrm{~m}^{3} / \mathrm{s}$ when the dry surface was measured after the flood event. The 5-m-intervals with RFID PIT tag equipped sediments recovered after the flood event are noted. Based on this count, the OCR was calculated (see Figure 10a). Geodata ( ) Research unit Ecohydrology, ZHAW. 


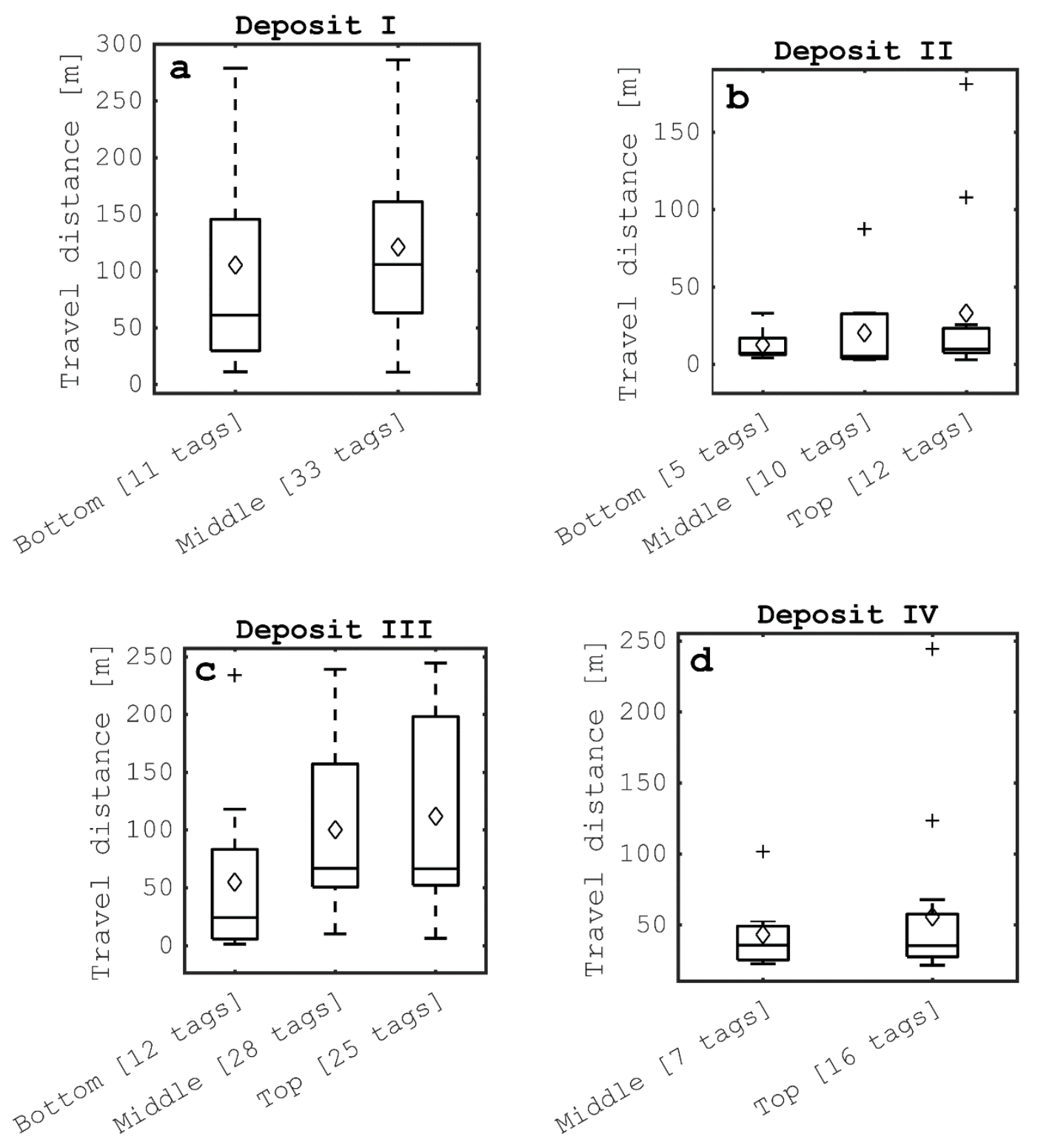

Figure 8. Transport distances from 159 of the 166 transported stones. The initial position of six stones was not clear. Stones from artificial deposit I and III were transported further than the others. 


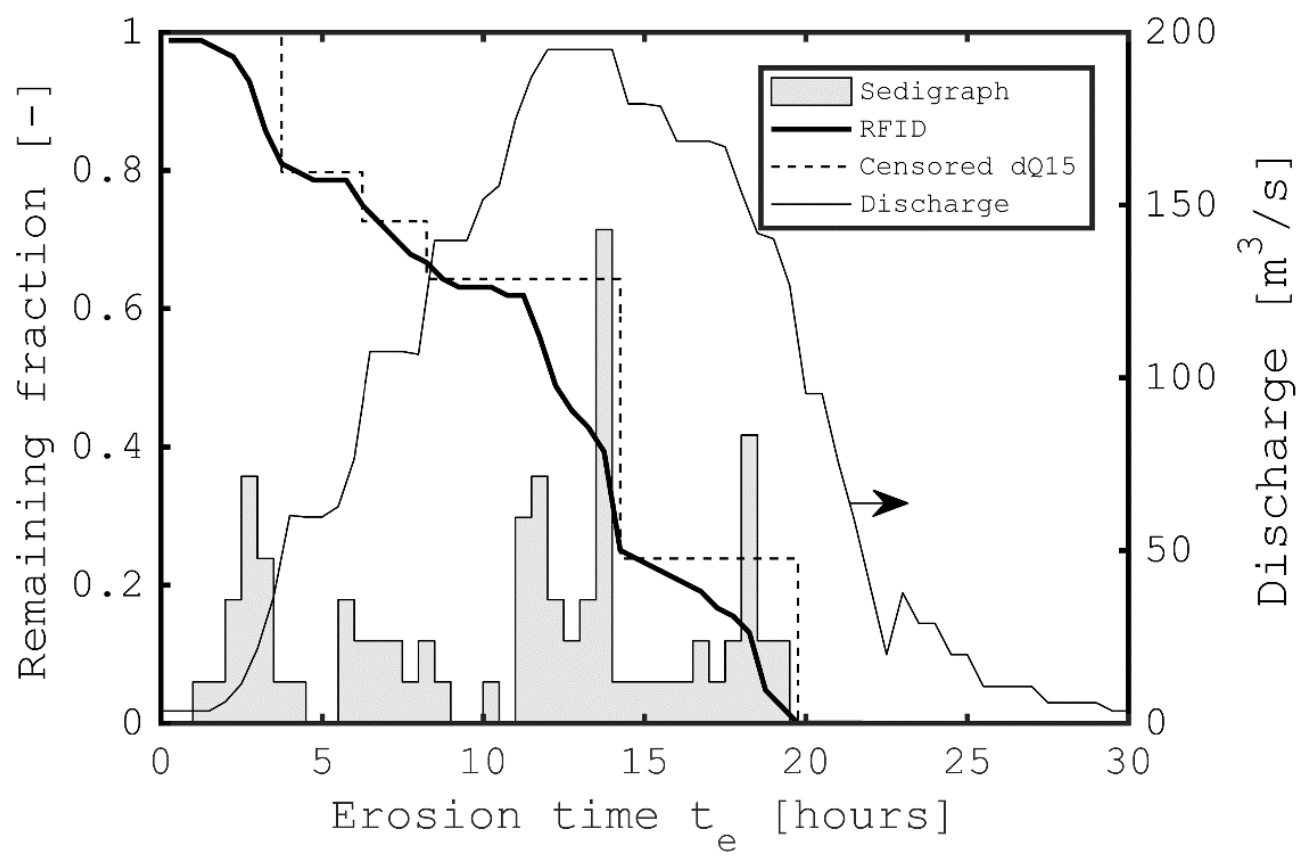

Figure 9. The erosion time represents the time that the 84 stones needed to leave the replenishment zone, on 125 PIT tagged stones recovered downstream of deposit IV. The survivor function (Davison and Hinkley 1997) indicates the proportion of stones remaining in the replenishment zone (84 stones $=100 \%$ ). To cluster the data, a censored analysis was done assembling all PIT tag-equipped stones leaving the zone within a change in discharge of 15 $\mathrm{m}^{3} / \mathrm{s}$ or higher. The sedigraph (shaded) represents the derivative of the survivor function, indicating the percentage of moved stones (84) that left the replenishment zone in a certain time interval, based on the virtual velocity analysis. It serves for illustrative purposes and does not refer to a y-axis, highest point is at 0.14 . 

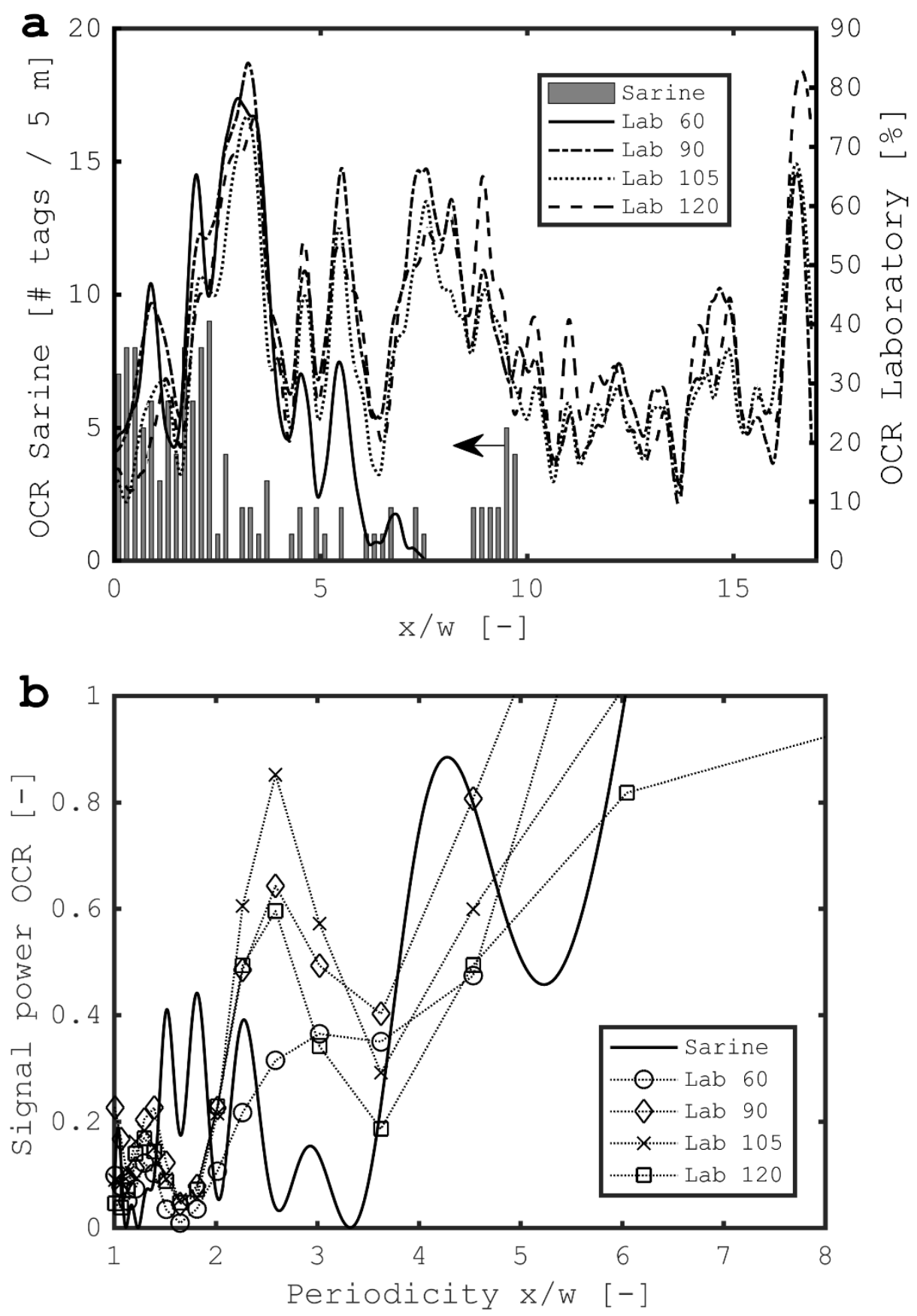

Figure 10. (a) Occupation ratio density (OCR) of the field experiment in the Sarine and the evolution of the laboratory experiments. Lab 60-120 are the results from the laboratory experiment after $60 \mathrm{~min}, 90 \mathrm{~min}$, etc. (b) Periodicity was calculated based on the signal power of the OCR. The two datasets were both normalized to be comparable in the same plot. The analyses are based on 125 PIT tagged stones. 


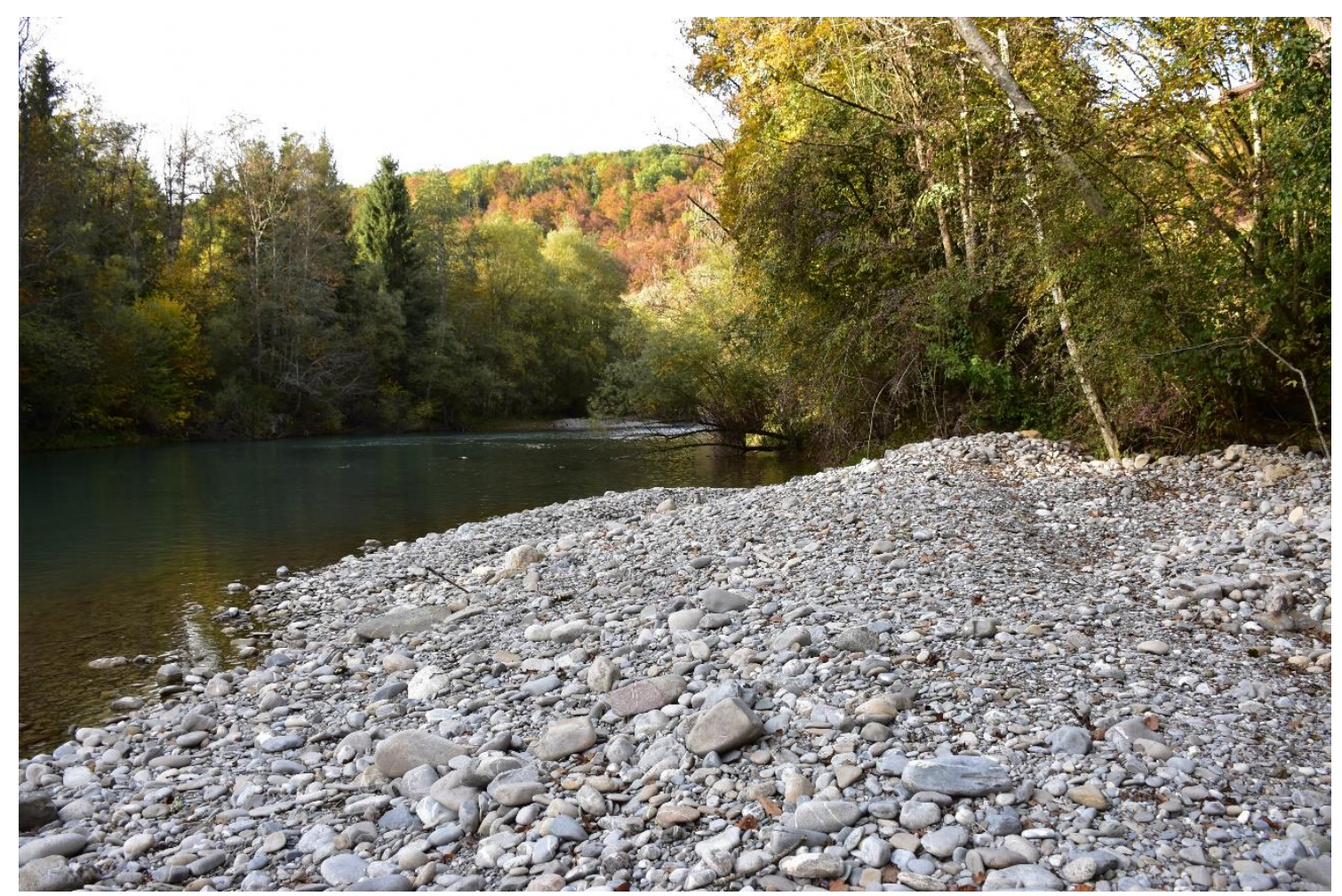

Figure 11: View from artificial deposit I towards upstream. An armoring of the residual artificial deposit was observed. The armoring was sorted with large stones in the bottom (left), where the submergence was higher and cobbles (right) where the submergence was smaller. Image: Severin Stähly. 